\title{
PLAGIOCLASE-MANTLED K-FELDSPAR IN THE CARBONIFEROUS PORPHYRITIC MICROGRANITE OF ALTENBERG-FRAUENSTEIN, EASTERN ERZGEBIRGE / KRUŠNÉ HORY
}

\author{
AXEL MÜLLER AND REIMAR SELTMANN
}

MÜLLER, AXEL and SELTMANN, REIMAR 2002. Plagioclase-mantled Kfeldspar in the Carboniferous porphyritic microgranite of Altenberg-Frauenstein, Eastern Erzgebirge/Krušné Hory. Bulletin of the Geological Society of Finland 74, Parts 1-2, 53-78.

The Upper Carboniferous porphyritic microgranite of Altenberg-Frauenstein, formerly known as Granitporphyr (Dalmer 1896) and here abbreviated as GP, forms a $36 \mathrm{~km}$ long and up to $18 \mathrm{~km}$ wide complex of ring dykes related to the Teplice-Altenberg caldera in the German-Czech border region of the Eastern Erzgebirge/Krušné Hory. The microgranites are characterized by the occurrence of plagioclase-mantled K-feldspar phenocrysts. The microgranite varieties represent two main stages of intrusion evolved from acid (GP I) to intermediate rocks (GP II) within the intrusion. The most acid rock (GP $\mathrm{I}_{\text {cum }}$ ) occurs as enclaves in GP I and GP II and is interpreted as a cumulate of K-feldspar and quartz phenocrysts. The porphyritic microgranites show field, textural and geochemical evidence suggesting that some of them have formed as a result of interaction between felsic and mafic magmas. Mixing features are abundant in the porphyritic quartz-feldspar-hornblende microgranite (GP II) interpreted as a hybrid rock. They are less discrete in the early phase (GP I) and not obvious in the acid enclaves (GP $\mathrm{I}_{\mathrm{cum}}$ ). This trend seems to reflect a continuous deflation of the magma chamber from the top to the bottom. According to the definition of rapakivi granites after Haapala and Rämö (1992), the porphyritic microgranite of Altenberg-Frauenstein may be considered as rapakivi granite although ovoid alkali feldspar megacrysts typical of classical rapakivi granites are not recorded. However, due to its Carboniferous age and being the only known granite with rapakivi texture in the German-Czech part of the Variscan belt, the microgranite of Altenberg-Frauenstein is exceptional.

Key words: granites, rapakivi, microgranite, porphyritic texture, phenocrysts, Kfeldspar, geochemistry, mineral composition, magma chambers, Carboniferous, Altenberg, Frauenstein, Erzgebirge, Germany

Axel Müller, Reimar Seltmann: Natural History Museum, Department of Mineralogy, Cromwell Road, London SW7 5BD, United Kingdom

E-mails:a.mueller@nhm.ac.uk,rs@nhm.ac.uk 


\section{INTRODUCTION}

The porphyritic microgranite of Altenberg-Frauenstein, a ring dyke fill of the Altenberg-Teplice caldera (ATC) in the Eastern Erzgebirge/Krušné Hory mountains (German-Czech border region), is part of the largest outcropping Carboniferous volcanic and subvolcanic suite of the Bohemian Massif (Hoth et al. 1995), which covers an area of $650 \mathrm{~km}^{2}$ (Fig. 1). Due to the rugged terrain and owing to intensive exploration drilling programs in the past 30 years in particular, the rocks and structure of the caldera are well documented.

The objective of this study is to explain the occurrence of plagioclase-mantled K-feldspar in the porphyritic microgranite of Altenberg-Frauenstein and to reconstruct the chemical, mineralogical, and textural evolution of a stratified silicic magma chamber.

Moesta (1928) first interpreted the complex of volcanic and subvolcanic rocks as a volcanotectonic depression (caldera). The magmatic stages of the ATC can be divided into five main phases (Benek et al. 1985, Reichmann et al. 1985, Jiránek et al. 1987, Štemprok et al. 1994, Breiter 1995, 1997, Seltmann \& Breiter 1995):

1) The $1^{\text {st }}$ volcano-sedimentary phase is represented by the Schönfeld unit composed of basal rhyolite tuffs followed by dacite lava flows and tuffs. At its base, the unit contains arkoses, sandstones, shales, and coal of Westphalian B/C $(311 \pm 2 \mathrm{Ma})$ age. The dacites are followed by a transitional volcano-sedimentary unit (Schönfeld beds) comprising rhyolite tuffs and/or ignimbrites in the south and mainly sediments (sands, coals) with only sporadic volcanogenic intercalations outcropping in the north of the ATC.

2) The $2^{\text {nd }}$ volcanic phase is represented by the Teplice rhyolites $(T R)$. The base is formed by an explosive phase (TR1), with rhyolitic tuffs and ignimbrites with thin intercalations of tuffaceous sandstones, clays, and coals which mainly crop out on the western margin of the Czech part of the TR. Plant remains in the sedimentary intercalations were dated as Westphalian C/D ( 308 Ma; Lobin 1983). From the Altenberg underground mine, such units were reported (W. Schilka and R.
Kühne, pers. comm.) as being later intruded by the porphyritic microgranite of Altenberg-Frauenstein.

3) The subsequent eruptions of the Teplice rhyolite belong to an explosive-effusive phase (TR2) characterized by lava flows, tuffs, and ignimbrites with a thickness of $300 \mathrm{~m}$.

4) The top is formed by the effusive-intrusive TR3 with rhyolitic to rhyodacitic ignimbrites and granite porphyries, building the bulk of the outcrops of the volcanic rocks within the ATC. The TR rhyolites cover the eastern third of the caldera on both sides of the state border. The total thickness of the volcanic rocks of the ATC amounts to nearly $2 \mathrm{~km}$. The preserved volcanic rocks represent more than $250 \mathrm{~km}^{3}$ of erupted magma (Jiránek et al. 1987, Benek 1991).

5) The eruption of this enormous volume from the magma chamber led to the collapse of the ATC with $\mathrm{N}-\mathrm{S}$ elongated pear-shaped ring fractures that were filled by the multiple intrusions of the porphyritic microgranite dyke complex of AltenbergFrauenstein forming a trap-door caldera (Benek 1991). The microgranites are dated at 307-309 Ma ( Ar/Ar plateau ages on separates of unaltered biotites, Seltmann \& Layer, unpubl., in Seltmann \& Schilka 1995). $\mathrm{Pb} / \mathrm{Pb}$ single zircon evaporation ages of around $330 \mathrm{Ma}$, interpreted by Kempe et al. (1999) to indicate intrusion age, were obtained from investigations on one microgranite sample only. The latter measurements $(n=5)$ indicate more likely ages of inherited zircons, because the reported age data are in conflict to the field relationships (the microgranites must be younger than the ATC volcanic rocks they intrude, e.g. Dalmer 1896). These zircons may be interpreted as xenocrysts that represent the older intrusions of the neighbouring Niederbobritzsch and Flaje I-type granite massifs (Seltmann et al. 2001), and the GP melt exhibiting similar I-type characteristics may be linked to the same magma reservoir at a later stage. Due to distortion of the U-Pb isotope system indicated by abnormal distribution patterns of the single ${ }^{207} \mathrm{~Pb} / 206 \mathrm{~Pb}$ measurements, ages from two zircon grains of around 305 Ma were not further discussed by Kempe et al. (1999), although 


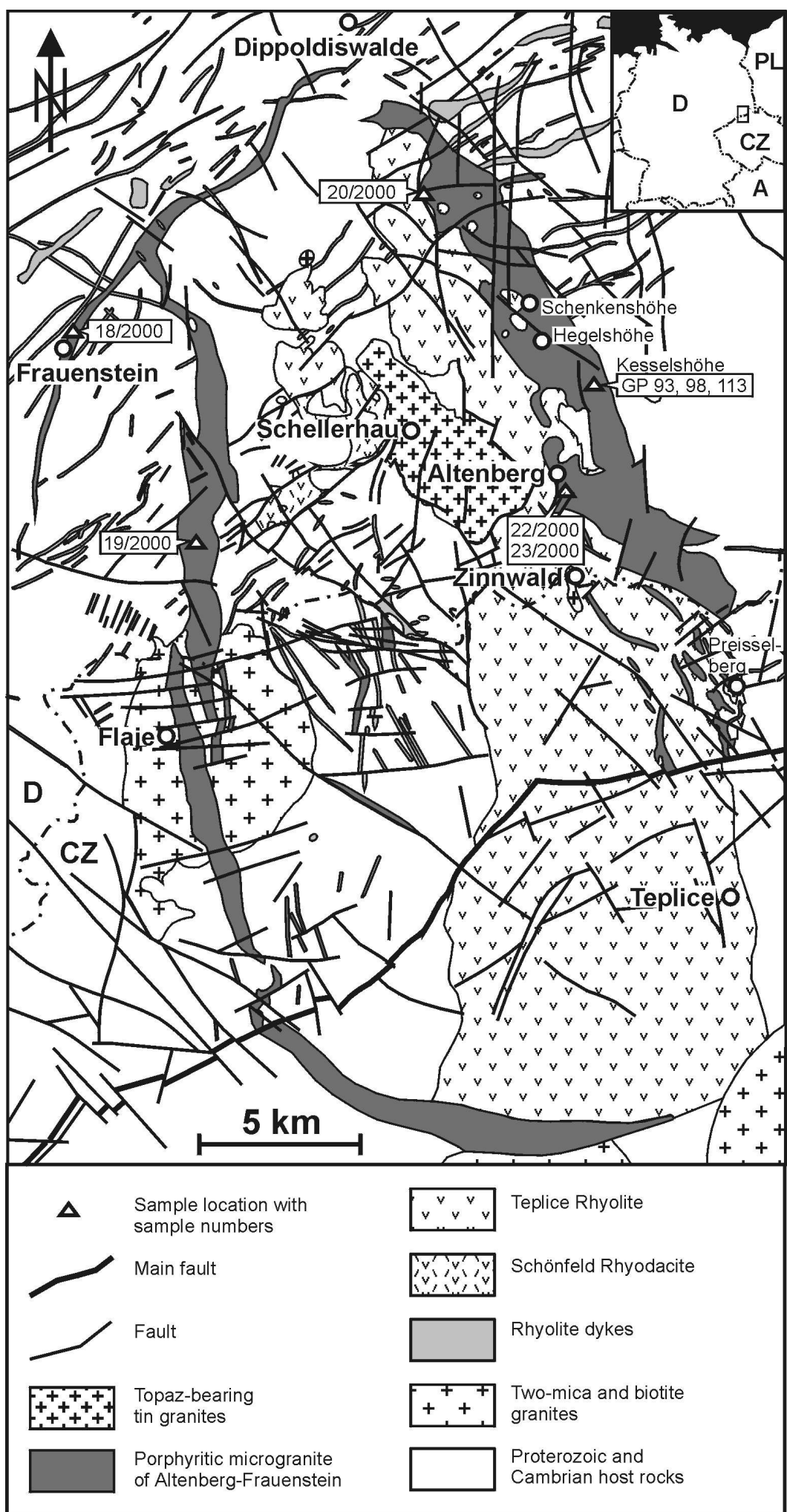

Fig. 1. Geological sketch map of the Altenberg-Teplice caldera, Mesozoic and Cenozoic uncovered. Based on Hoth et al. (1995) and Mlčoch (1994). 

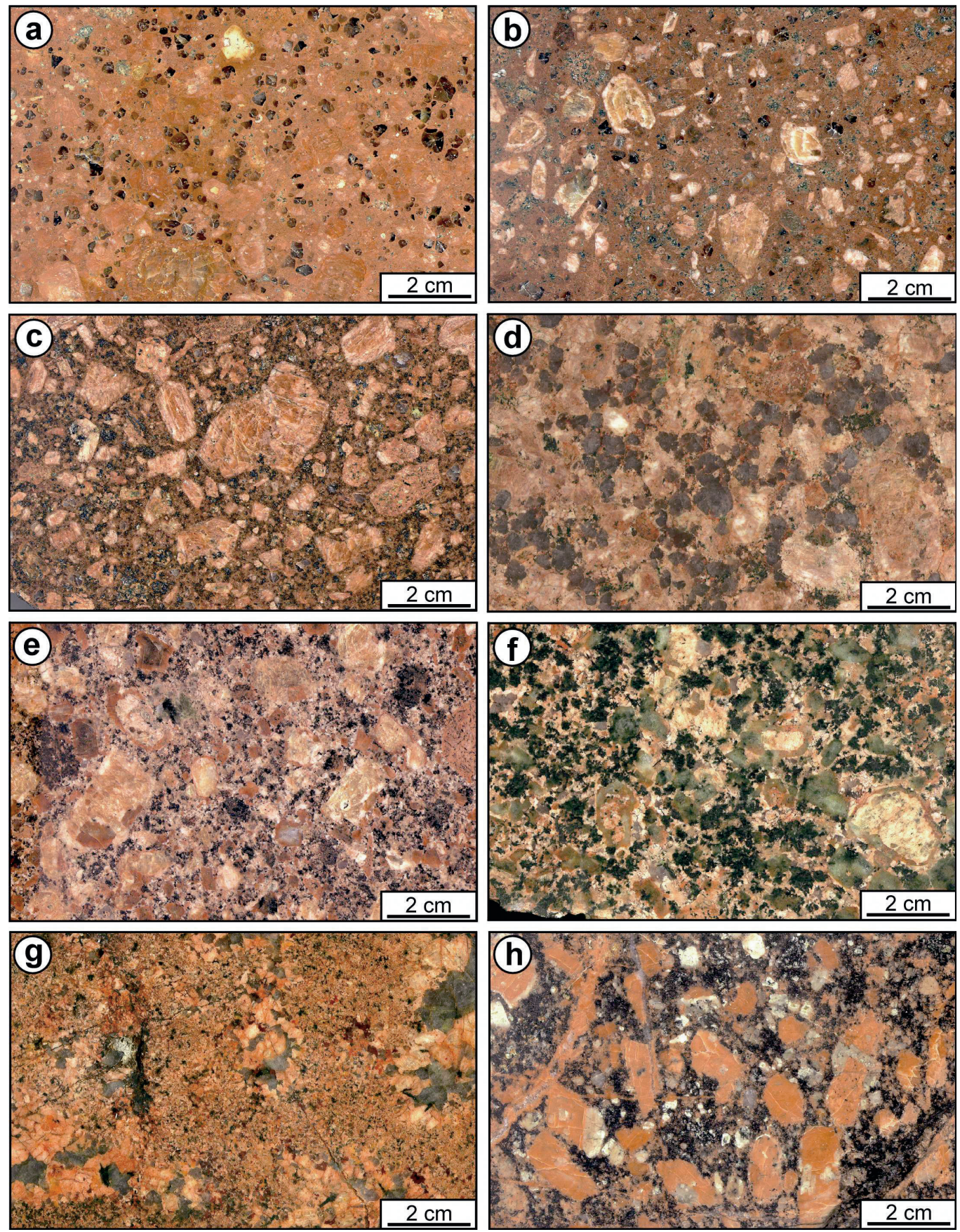

Fig. 2. Textural varieties of the porphyritic microgranite of Altenberg-Frauenstein within its intrusion phases (I - II). a - Quartz-phenocryst-rich porphyritic feldspar-quartz microgranite GP $I_{q z}(20 / 2000)$. b - porphyritic feldspar-quartz microgranite GP I (18/2000). c - K-feldspar-rich porphyritic feldspar-quartz microgranite GP $I_{f s}$ (19/2000). d-medium- to coarse-grained microgranite GP I cum (GP 93). e-porphyritic feldspar-quartz-hornblende microgranite GP II with granophyric matrix (23/2000). $f$ - mafic schliere within the feldspar-quartz-hornblende microgranite GP $I I_{h b l}\left(G P\right.$ 113). g-miarolitic microgranite $G P I I_{m}(G P$ 98). $h$ - greisenized feldsparquartz-hornblende microgranite GP $I I_{g s}(22 / 2000)$. 


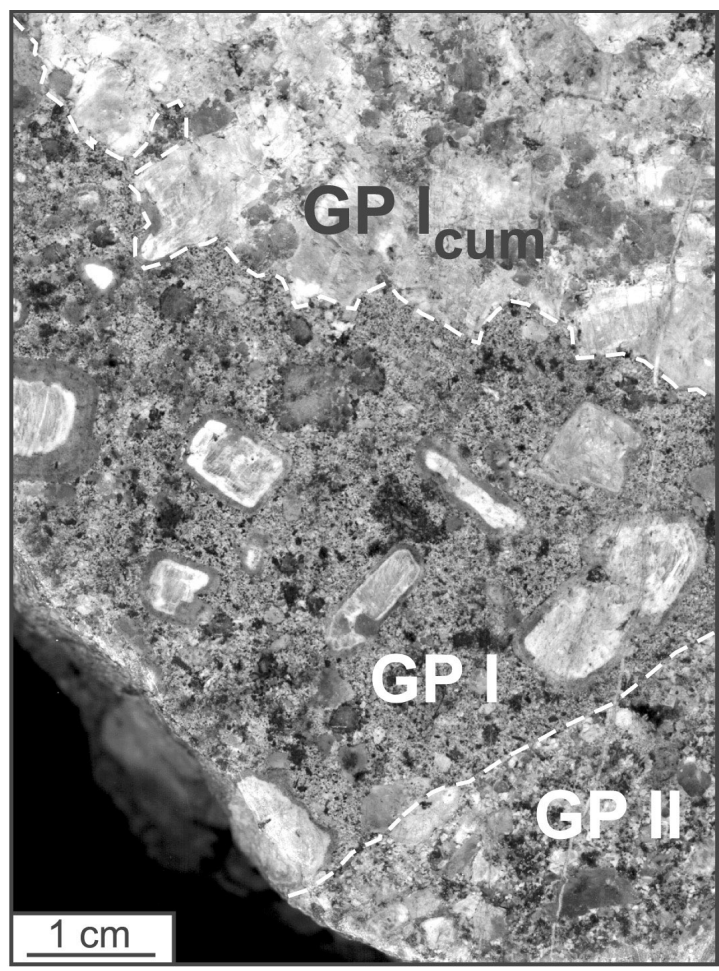

Fig. 3. Microgranite hand specimen (GP 93) with textural variations from the quarry at Kesselhöhe north of Altenberg. It shows the sharp contacts between enclave GP I $I_{\text {cum }}$ (for petrographic characteristics and chemical analyses of that zone see Tab. 1 and Tab. 2), GP I and GP II.

this age is in better accordance with the geological field relations (and is in the range of the Ar/ Ar ages reported above).

The caldera collapse was later followed by multiple intrusions of highly differentiated rare metal-bearing, high-silica, A-type granites of Zinnwald, Schellerhau, and Preisselberg (Breiter et al. 1991).

\section{GEOLOGICAL SETTING}

The microgranites of Altenberg-Frauenstein show wide textural and geochemical variations (Müller \& Seltmann 2001, Seltmann et al. 2001). Field documentation allowed the reconstruction of the age relationships and classification of chemically and texturally distinct GP I and GP II sequences of intrusive phases that are characterized by sharp intrusive contacts. The granite porphyries intrude in the sequence (Fig. 2): 1) K-feldspar phenocrystpoor porphyritic feldspar-quartz microgranite with fine-grained matrix (GP I), 2) porphyritic feldsparquartz-hornblende microgranite with granophyric matrix (GP II). The latter may locally contain mafic schlieren (GP $\mathrm{II}_{\mathrm{hbl}}$ ) and phenocryst-free miarolitic zones $\left(\mathrm{GP} \mathrm{II}_{\mathrm{m}}\right)$. The most acid mediumto coarse-grained microgranite $\left(\mathrm{GP} \mathrm{I}_{\mathrm{cum}}\right)$ occurs as enclaves in GP I and GP II (Fig. 3). The ring dyke complex is dominated by GP I, with less common occurrences of more mafic batches of GP II. The varieties $\mathrm{GP}_{\mathrm{cum}}$, GP $\mathrm{II}_{\mathrm{hbl}}$, and $\mathrm{GP} \mathrm{II}_{\mathrm{m}}$ are rare and occur mapable only in the $\mathrm{E}$ dyke in the vicinity of Altenberg. Pegmatite and aplite schlieren, several meters in size, coarse-grained phenocryst-rich porphyritic varieties (obviously forming a marginal facies of GP II), and phenocryst-free microgranitic varieties (with sharp contact to GP II and interpreted as GP III, Seltmann et al. 2001) seem to be local phenomena and occupy only a very minor volume. They were observed along with all the other textural varieties predominantly in the active quarry at Kesselhöhe north of Altenberg.

\section{PETROGRAPHY}

\section{Porphyritic feldspar-quartz microgranite with fine-grained matrix (GP I)}

Red-brown porphyritic feldspar-quartz microgranite forms W, NW and S trending dykes and portions of the eastern dykes (Figs. 2 a, b, c, 4a, b, c). It represents the silicic member of the complex. Phenocrysts include K-feldspar (23 vol\%) up to $4 \mathrm{~cm}$ in size, quartz (9 vol\%), and minor plagioclase (7 vol\%; Table 1; Fig. 5). Up to $8 \%$ of the $\mathrm{K}$-feldspar phenocrysts are mantled by plagioclase representing rapakivi texture sensu lato (Rämö \& Haapala 1995). The existence of mantled Kfeldspar phenocrysts within the microgranite of Altenberg-Frauenstein was first mentioned by Dalmer (1896). He described "pink" K-feldspar phenocrysts which are enveloped by a "red" (weathered) feldspar shell. Beside euhedral, mineral inclusion-free plagioclase phenocrysts there 

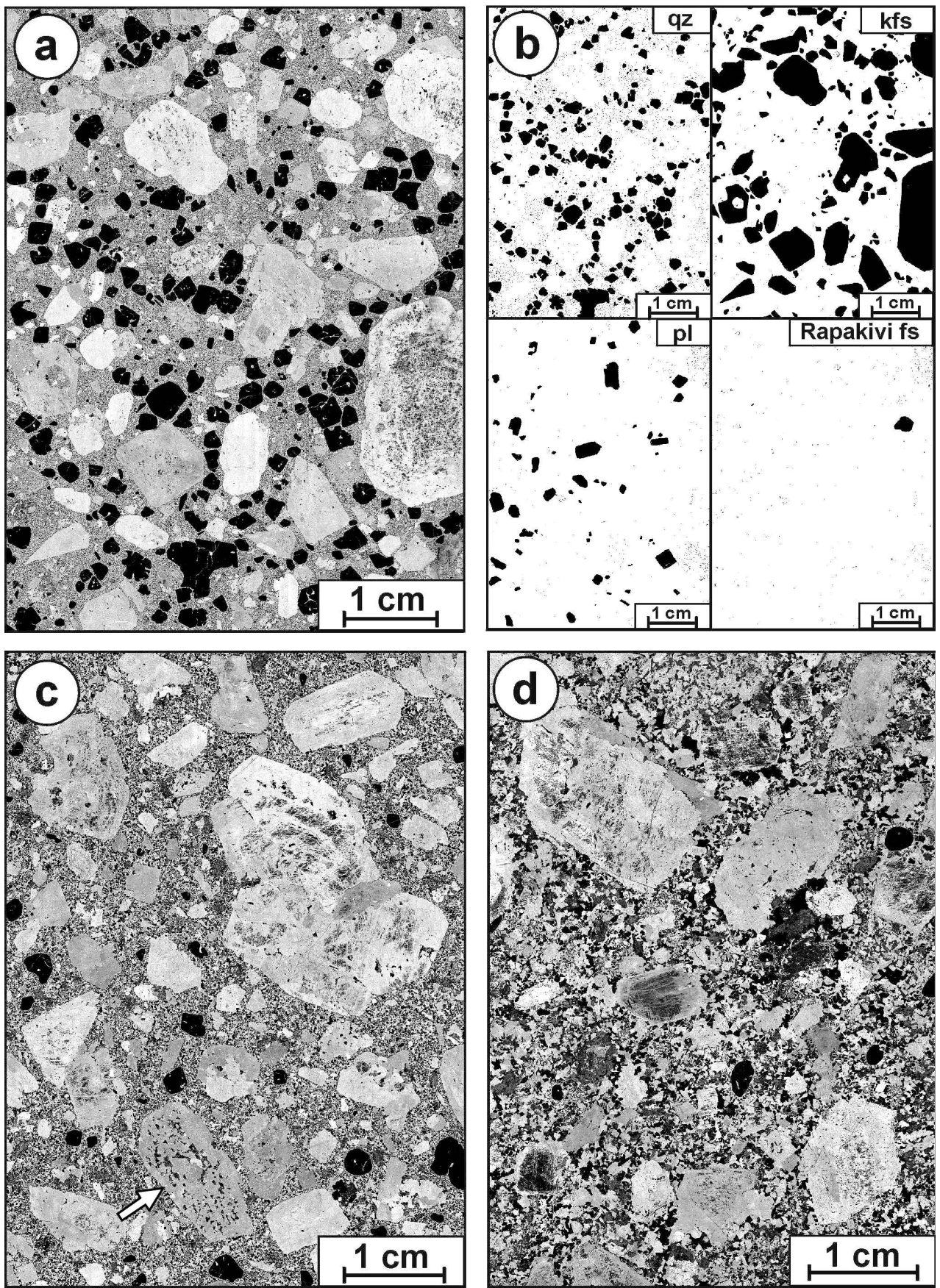

Fig. 4. Black and white copies of lacquer peels. Quartz appears black, biotite dark grey, feldspar white to grey. Plagioclase and $K$-feldspar can not be distinguished in the lacquer peels. a-Quartz-phenocryst-rich GP $I_{q z}$ with 59 vol\% phenocryst content $(q z+f s)$ and aplitic matrix. $b-$ Processed images of separated phenocryst species for content determination using lacquer peels (a) and hand specimen scans. $c-K$-feldspar-rich $G P I_{f s .}$ Note the sieve-textured plagioclase phenocryst (indicated by the white arrow). $d-G P$ II with granophyric matrix. Figs. $4 a, c, d$ refer to samples shown in Figs. $2 a, c, e$. 
Table 1. Petrographic characteristics of the main varieties of the porphyritic microgranite of AltenbergFrauenstein.

\begin{tabular}{|c|c|c|c|c|c|c|c|c|}
\hline \multirow{2}{*}{$\begin{array}{l}\text { variety } \\
\text { (sample \#) }\end{array}$} & \multicolumn{5}{|c|}{ phenocryst content (vol.\%) } & \multirow[t]{2}{*}{ matrix } & \multirow[t]{2}{*}{ mafic minerals } & \multirow[t]{2}{*}{ main accessories } \\
\hline & $\mathrm{qz}$ & $\mathrm{kfs}$ & $\begin{array}{l}\text { mantled } \\
\mathrm{kfs}\end{array}$ & $\mathrm{pl}$ & sum & & & \\
\hline $\begin{array}{l}\mathrm{GP} \mathrm{I}_{\mathrm{qz}} \\
(20 / 2000)\end{array}$ & 18 & 34 & 1 & 6 & 59 & fine-grained & biotite, epidote & zircon, apatite,titanomagnetite \\
\hline $\begin{array}{l}\text { GP I } \\
(18 / 2000)\end{array}$ & 9 & 23 & 2 & 7 & 41 & fine-grained & biotite, epidote & zircon, apatite,titanomagnetite \\
\hline $\begin{array}{l}\text { GP I } I_{\mathrm{fs}} \\
(19 / 2000)\end{array}$ & 8 & 37 & 2 & 9 & 56 & fine-grained & biotite, epidote & zircon, apatite,titanomagnetite \\
\hline $\begin{array}{l}\text { GP I }{ }_{\text {cum }} \\
(93)\end{array}$ & 24 & 28 & 0 & 3 & 55 & medium-grained & biotite & zircon, apatite \\
\hline $\begin{array}{l}\text { GP II } \\
(23 / 2000)\end{array}$ & 1 & 28 & 6 & 13 & 48 & $\begin{array}{l}\text { fine-grained, } \\
\text { qtz-kfs } \\
\text { intergrowth }\end{array}$ & $\begin{array}{l}\text { biotite, } \\
\text { hornblende, } \\
\text { epidote }\end{array}$ & $\begin{array}{l}\text { zircon, apatite, } \\
\text { titanomagnetite, allanite, } \\
\text { monazite, xenotime }\end{array}$ \\
\hline $\begin{array}{l}\text { GP II } \\
(113)\end{array}$ & 2 & 6 & 7 & 20 & 35 & $\begin{array}{l}\text { fine-grained, } \\
\text { qtz-kfs } \\
\text { intergrowth }\end{array}$ & $\begin{array}{l}\text { biotite, } \\
\text { hornblende, } \\
\text { epidote }\end{array}$ & $\begin{array}{l}\text { zircon, apatite, } \\
\text { titanomagnetite, allanite, } \\
\text { monazite, xenotime }\end{array}$ \\
\hline $\begin{array}{l}\mathrm{GP} \mathrm{II}_{\mathrm{gs}} \\
(22 / 2000)\end{array}$ & 2 & 32 & 5 & 16 & 55 & $\begin{array}{l}\text { fine-grained, } \\
\text { qtz-kfs } \\
\text { intergrowth, } \\
\text { greisenized }\end{array}$ & $\begin{array}{l}\text { biotite, } \\
\text { hornblende, } \\
\text { epidote }\end{array}$ & $\begin{array}{l}\text { zircon, apatite, } \\
\text { titanomagnetite, } \\
\text { allanite, monazite, } \\
\text { xenotime }\end{array}$ \\
\hline $\begin{array}{l}\text { GP II } \\
\text { (98) }\end{array}$ & 0 & 0 & 0 & 0 & 0 & miarolitic & biotite & zircon, apatite \\
\hline
\end{tabular}

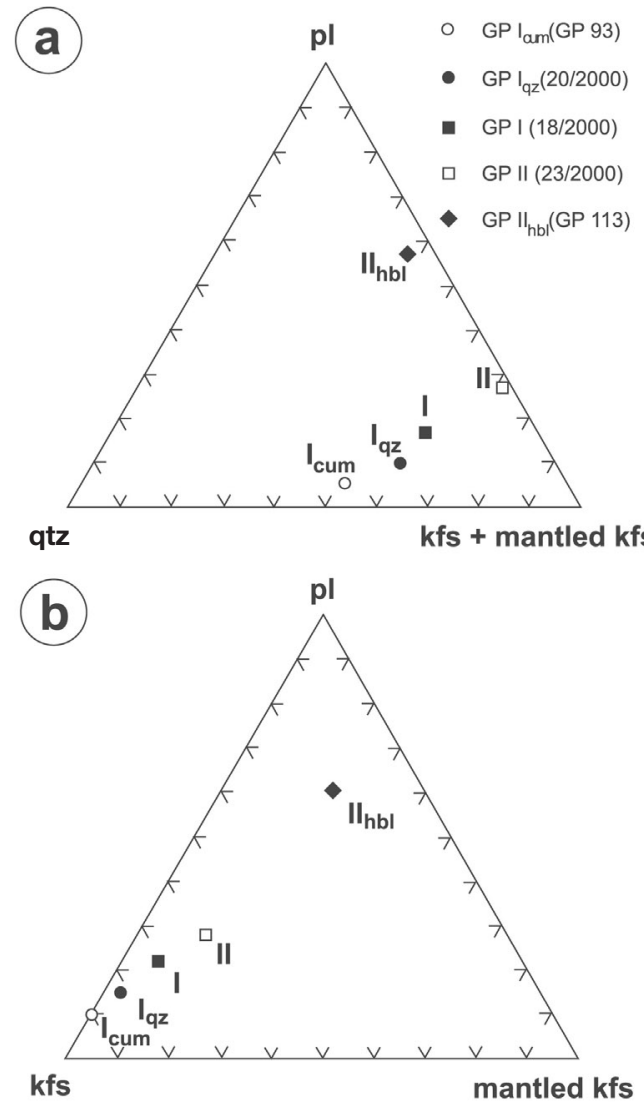

Fig. 5. Ternary diagrams illustrating phenocryst portions of quartz, plagioclase, and $K$-feldspar plus mantled $K$-feldspars (a) and plagioclase, $K$-feldspar, and mantled $K$-feldspar (b) in the varieties of the porphyritic microgranite of Altenberg-Frauenstein GP I and II. From the first $K$-feldspar-quartz-rich silicic GP I the phenocryst content changes to plagioclase-rapakivifeldspar-rich intermediate GP II. The phenocryst distribution reflects the chemical trend. 

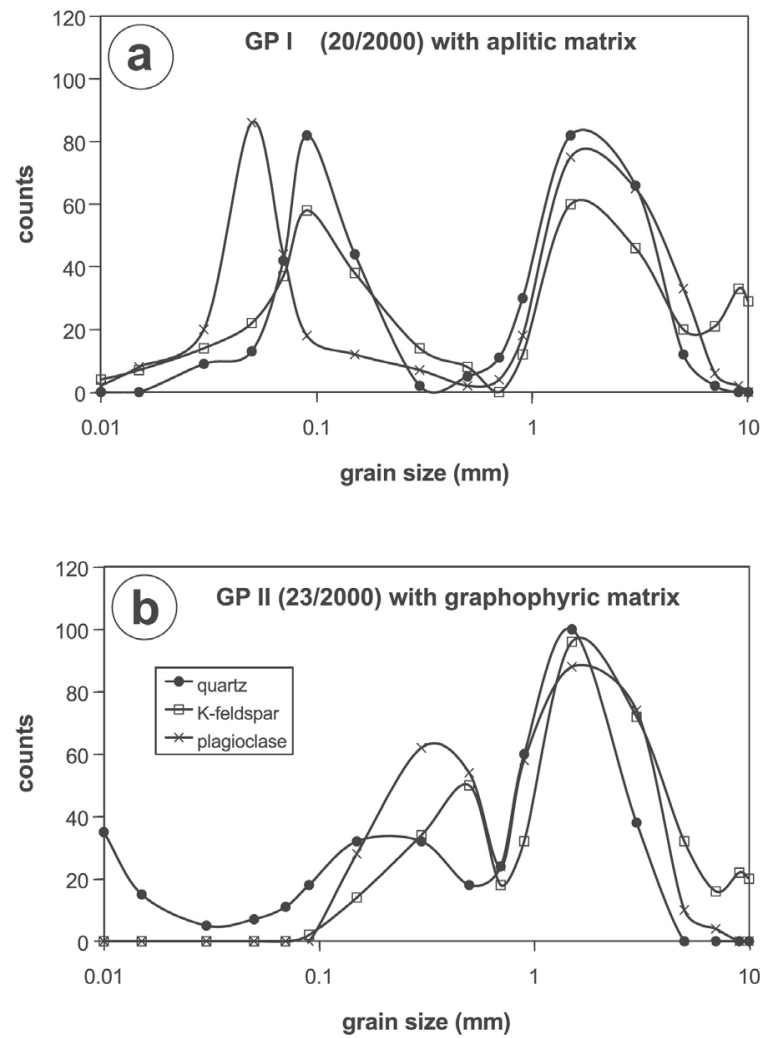

Fig. 6. Grain size distribution plots of quartz and feldspars. The matrix minerals of GP $I_{q z}$ and GP II show a variable grain size reflecting different cooling conditions. In contrast phenocrysts ( $>0.7 \mathrm{~mm})$ of both varieties have a constant grain size indicating a pre-intrusion existence. Note the third $K$-feldspar peak at $9 \mathrm{~mm}$. We interpret this peak as a special $K$-feldspar facies which crystallises faster near the magma chamber wall due to higher undercooling (see Fig. 16). Grain sizes $0.5 \mathrm{~mm}$ were measured from the thin section whereas grain sizes $>0.5 \mathrm{~mm}$ were measured from $10 \times 10 \mathrm{~cm}$ hand specimen. Both data were normalized to 100.

are also some ovoid to euhedral sieve-textured phenocrysts with common inclusions of biotite, epidote, titanomagnetite, and quartz (Fig. 4c). Quartz occurs as rounded or euhedral grains between 1 and $5 \mathrm{~mm}$ in diameter; biotite and subhedral albite are present in the fine-grained matrix. The matrix minerals exhibit a sharp peak in the grain size distribution plot. A large grain size hiatus exists between matrix and phenocryst minerals (Fig. 6). North of the E dyke is found a rare quartz-phenocryst-rich variety $\left(\mathrm{GP} \mathrm{I}_{\mathrm{qz}}\right)$ with up to 20 vol.\% quartz phenocrysts (Figs. 2a, 4a). The lacquer peel method (Behr 1966) has been applied (Fig. 4) to contrast the magmatic textures in hand specimen, specifically to distinguish quartz and feldspar textures and to determine the volume proportions of phenocrysts.

\section{Porphyritic feldspar-quartz-hornblende microgranite with granophyric matrix (GP II)}

In the E dyke, close of Altenberg, occurs the porphyritic feldspar-quartz-hornblende microgranite. The rock is rich in mafic minerals and represents the most mafic member of the dyke complex (Figs. 2e; 4d; 5). The GP II contains hbl-bt-pl-rich schlieren (Fig. 2f; GP $\mathrm{II}_{\mathrm{hbl}}$ ) which have diffuse contact with the host. The variety of GP II with dark grey groundmass is limited to localities such as the abandoned Altenberg tin mine and Hegelshöhe NW of Altenberg (Fig. 2h; GP II ${ }_{g s}$ ). The dark groundmass color is caused by formation of biotite and chlorite during greisenization and contact metamorphism related to tin granites.

Up to $60 \%$ of the K-feldspar megacrysts are mantled by plagioclase. No clearly rounded, ovoidal alkali feldspar megacrysts, typical to the Finnish rapakivi granites, are recorded. Some of the quartz as well as K-feldspar megacrysts are corroded as recognised by their truncated growth zoning (Fig. 7a, b). Resorbed quartz phenocrysts are partly mantled by microcrystalline plagioclase, biotite, and titanomagnetite. Cathodoluminescence makes it possible to see the complex growth history of such phenocrysts. The grain size distribution plots of GP II and GP I show a constant grain size of the phenocrysts in both varieties which is evidence for their existence as phenocrysts prior to intrusion and final crystallisation of the groundmass (Fig. 6).

The matrix is characterized by granophyric intergrowths of quartz and K-feldspar which overgrow the phenocrysts (Fig. 7a, c, d). The intergrowths are composed of radiating quartz and $\mathrm{K}$ feldspar stringers at the surface of pre-existing feldspar and quartz phenocrysts and form fan-like, in some cases dendritic fern-like structures. The 

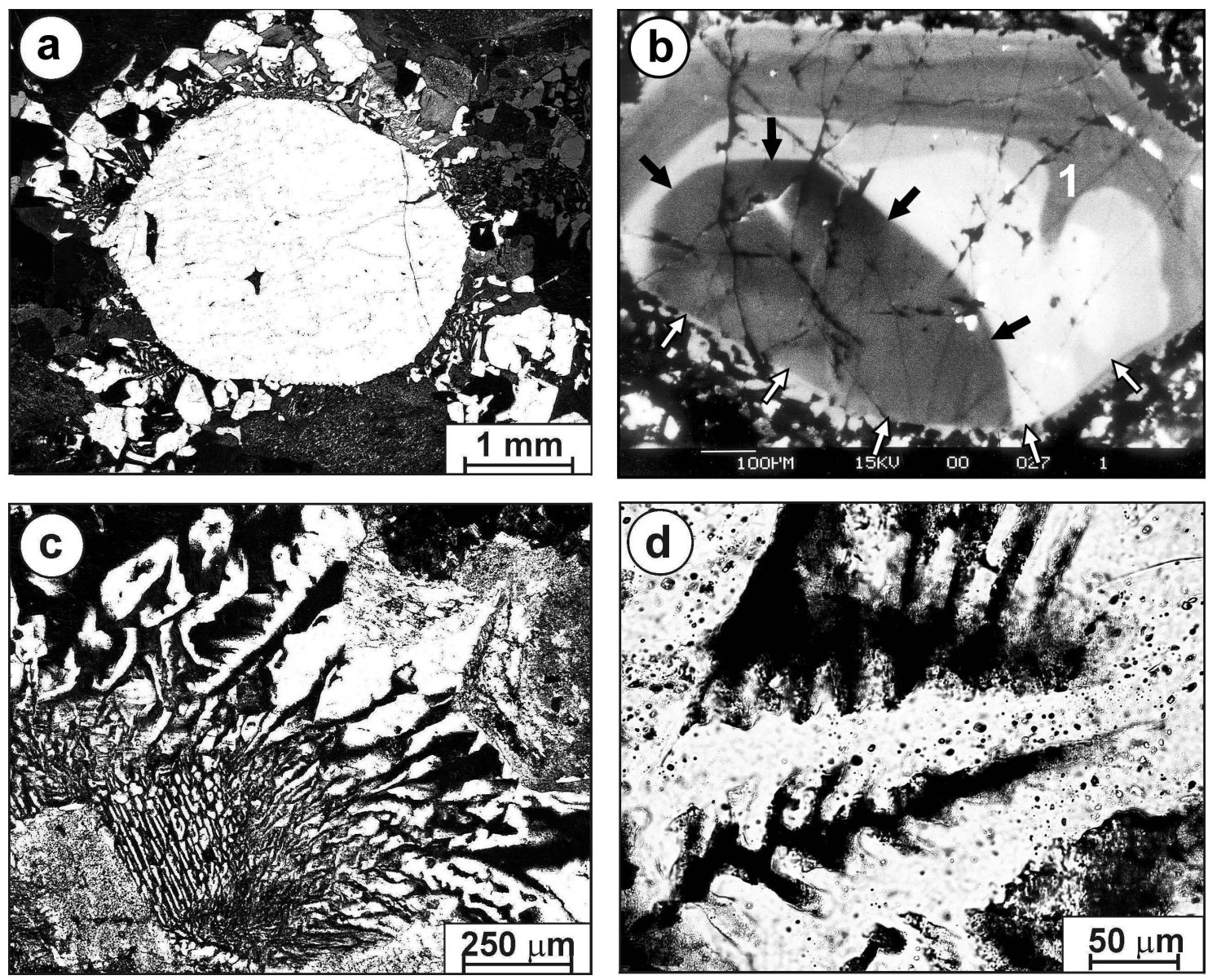

Fig. 7. Photomicrographs of magmatic textures in the porphyritic microgranites. a-Rounded quartz phenocryst in GP II with a granophyric quartz corona with the same crystallographic orientation. Crossed nicols. $b-S E M-$ cathodoluminescence image of a resorbed quartz phenocryst in GP II with truncated previous zoning. The phenocryst exhibits two resorbtion events, the first one reflected by rounding of the core (indicated by black arrows), the second one is possibly following a fracturing event (indicated by white arrows). Note the lobate embayment within the zoning pattern in the right half of the crystal (1) which is interpreted as a healed growth impediment. $c$-Graphic quartz in the outer margin of a K-feldspar phenocryst (GP II). The contact between quartz-free feldspar and graphic quartz feldspar intergrowths follows crystallographic faces. Crossed nicols. $d-D e n d r i t i c$ intergrowth of quartz (white) with K-feldspar (black). Crossed nicols.

overgrowths have the same crystallographic orientation as the seed crystals. Matrix crystals exhibit a broad grain size distribution (Fig. 6b). The matrix quartz intergrown with K-feldspar shows a saddle-like distribution.

Mafic minerals of the matrix are concentrated in spherical clusters (globules), 1 to $5 \mathrm{~mm}$ in diameter, consisting of biotite, epidote, hornblende, plagioclase, apatite, titanomagnetite, and ilmenite surrounded by a corona of K-feldspar. Euhedral hornblende exhibits reaction rims of fine-crystalline biotite. The occurrence of pyroxene mentioned by Pälchen (1968) in bt-rich varieties was not observed in our samples. Acicular apatite is a frequent accessory mineral in GP II, but rare in the more silicic microgranites (GP I). In the clusters characteristically occur Ce-rich allanite as subhedral strip-like crystals and as reaction rims 
on titanomagnetite. At the contact between Ca-rich plagioclase and K-feldspar, symplectic intergrowths are developed.

The medium- to coarse-grained microgranite is the most acid variety of the microgranites of Altenberg-Frauenstein (GP $\mathrm{I}_{\text {cum }}$ ) and occurs as enclaves within GP I and GP II (Fig. 2d, Fig. 3). This type is characterized by a high $\mathrm{K}$-feldspar and quartz phenocryst content of up to $60 \mathrm{vol} \%$. As in GP II, the K-feldspar of the matrix commonly shows granophyric intergrowths with quartz. The rock contains neither mafic schlieren nor plagioclase-mantled K-feldspars.

Associated with GP II are miarolitic cavities $\left(\mathrm{GP} \mathrm{II}{ }_{\mathrm{m}}\right.$ ) that are free of phenocrysts (Fig. $2 \mathrm{~g}$ ). The fabric is developed as an interconnected miarolitic texture (Candela \& Blevin 1995), which consists of micropegmatitic miaroles that form a three-dimensional interconnected network. The size of the miaroles embedded in fine-grained matrix is up to $10 \mathrm{~cm}$.

\section{GEOCHEMISTRY}

Eight samples representative of the porphyritic microgranite intrusion sequence were selected for chemical analysis (Table 2). Major and trace elements were determined by inductively coupled plasma - atomic emission spectrometry (ICPAES) at the laboratories of the Natural History Museum in London. Fluorine was separated by pyrohydrolysis and determined by ion chromatography; $\mathrm{H}_{2} \mathrm{O}$ and $\mathrm{CO}_{2}$ were obtained with the $\mathrm{CHN}$ analyzer. Complementary trace elements (REE, Y, $\mathrm{Zr}, \mathrm{Hf}, \mathrm{Rb}, \mathrm{Sr}, \mathrm{Ba}, \mathrm{Cs}, \mathrm{Pb}, \mathrm{U}, \mathrm{Th}$ ) were analyzed by inductively coupled plasma - mass spectrometry (ICP-MS) at the GeoForschungsZentrum (GFZ) Potsdam. Whole rock chemistry (Table 2) matches the general trends discussed in earlier publications (Seltmann \& Schilka 1995, Seltmann $\&$ Breiter 1995) and progress is reported in a companion paper (Seltmann et al. 2001).

The chemical evolution patterns of the microgranite intrusion sequence (Fig. 8, Fig. 9) correlate well with its textural and mineralogical characteristics. In the REE plot the GP I and II show
(Fig. 8) a similar fractionation degree, with a pronounced LREE enrichment over HREE and pronounced Eu minimum. The Eu minimum for GP $\mathrm{II}_{\mathrm{hbl}}$ is less deep than for its precursors GP I and GP II because the mafic schlieren are rich in hornblende, plagioclase, and REE-bearing accessory minerals. The GP $\mathrm{I}_{\text {cum }}$ and GP $\mathrm{II}_{\mathrm{m}}$ varieties have again lower concentrations of both LREE and HREE, and show the Eu minimum characteristic of the whole sequence. This corresponds to the quartz- and feldspar-rich cumulate character of the GP $I_{\text {cum }}$ and its depletion in other REE carriers. The GP I-II sequence shows in the plot only weakly developed REE tetrad effects (Irber 1999), indicating only slight alteration by fluid saturation for the miarolitic GP $\mathrm{II}_{\mathrm{m}}$.

Similar evolution trends are observed in the $\mathrm{Zr} /$ $\mathrm{Hf}-\mathrm{SiO}_{2}$ plot (Fig. 9). The quartz-rich GP $\mathrm{I}_{\mathrm{qz}}$ shows low $\mathrm{Zr} / \mathrm{Hf}$ and has up to $74 \mathrm{wt} \% \mathrm{SiO}_{2}$, and it is followed by the main eruption phases of GP I-II towards the most mafic end-member of GP $\mathrm{II}_{\text {hbl }}$ with lower $\mathrm{SiO}_{2}$ (from 69 to 64 wt.\%) and elevated $\mathrm{Zr} / \mathrm{Hf}$ (38-43).

Compared to classic rapakivi granites, which are Precambrian A-type granites (Haapala \& Rämö 1992), the studied porphyritic microgranite is of Upper Carboniferous age (Westphalian; Seltmann \& Breiter 1995) but exhibits A-type characteristics as shown in Fig. 10. They show some interesting chemical similarities, e.g. the I-type tendency of GP $\mathrm{I}_{\text {cum }}$, with the older intrusions of the nearby Niederbobritzsch and Flaje I-(S) type granite massifs (Förster \& Tischendorf 1994), which are of Namurian age (A. von Quadt, pers. comm.; Seltmann \& Breiter 1995, Werner \& Lippolt 1998) and are postdated by lamprophyres.

\section{MINERAL COMPOSITIONS}

A systematic electron microprobe investigation was carried out on feldspar, hornblende, and biotite with a Cameca SX 50 microprobe at the Natural History Museum London, using an accelerating voltage of $15 \mathrm{kV}$ and a beam current of 15 nA. 
Table 2. Chemical constitution of the main varieties of the porphyritic microgranite of Altenberg-Frauenstein.

\begin{tabular}{|c|c|c|c|c|c|c|c|c|}
\hline $\begin{array}{l}\text { Туре } \\
\text { Sample }\end{array}$ & $\begin{array}{c}\mathbf{G P ~ I}_{\mathbf{q z}} \\
20 / 2000\end{array}$ & $\begin{array}{r}\mathbf{G P} \mathbf{I}_{\mathrm{fs}} \\
19 / 2000\end{array}$ & $\begin{array}{r}\text { GP I } \\
18 / 2000\end{array}$ & $\begin{array}{r}\text { GP I } \\
\text { GP } 93\end{array}$ & $\begin{array}{c}\text { GP II } \\
22 / 2000\end{array}$ & $\begin{array}{r}\text { GP II } \\
23 / 2000\end{array}$ & $\begin{array}{c}\mathbf{G P} \mathbf{I I}_{\mathbf{h b l}} \\
\text { GP } 113\end{array}$ & $\begin{array}{r}\mathbf{G P} \mathbf{I I}_{\mathbf{m}} \\
\text { GP } 98\end{array}$ \\
\hline \multicolumn{9}{|c|}{ Major elements (wt\%) } \\
\hline $\mathrm{SiO}_{2}$ & 73.8 & 68.8 & 68.7 & 72.9 & 66.1 & 65.8 & 64.1 & 74.5 \\
\hline $\mathrm{TiO}_{2}$ & 0.21 & 0.45 & 0.48 & 0.18 & 0.59 & 0.55 & 0.75 & 0.15 \\
\hline $\mathrm{Al}_{2} \mathrm{O}_{3}$ & 12.8 & 14.5 & 14.3 & 13.2 & 14.1 & 14.4 & 15.3 & 13.1 \\
\hline $\mathrm{tFe}_{2} \mathrm{O}_{3}$ & 1.38 & 3.61 & 3.73 & 1.67 & 4.96 & 3.92 & 5.53 & 0.97 \\
\hline $\mathrm{MnO}$ & 0.016 & 0.038 & 0.046 & 0.055 & 0.068 & 0.074 & 0.107 & 0.033 \\
\hline $\mathrm{MgO}$ & 0.11 & 0.54 & 0.74 & 0.25 & 0.66 & 0.83 & 1.24 & 0.17 \\
\hline $\mathrm{CaO}$ & 0.21 & 0.77 & 0.62 & 1.06 & 1.95 & 1.31 & 2.23 & 0.42 \\
\hline $\mathrm{BaO}$ & 0.044 & 0.082 & 0.079 & 0.048 & 0.083 & 0.098 & 0.122 & 0.04 \\
\hline $\mathrm{Na}_{2} \mathrm{O}$ & 2.77 & 3.32 & 3.38 & 2.56 & 3.09 & 3.07 & 3.71 & 2.28 \\
\hline $\mathrm{K}_{2} \mathrm{O}$ & 6.76 & 6.57 & 6.59 & 6.75 & 6.35 & 6.73 & 5.07 & 7.66 \\
\hline $\mathrm{H}_{2} \mathrm{O}+$ & 0.72 & 1.05 & 1.11 & 0.48 & 0.85 & 1.04 & 1.44 & 0.49 \\
\hline $\mathrm{P}_{2} \mathrm{O}_{5}$ & 0.07 & 0.15 & 0.15 & 0.05 & 0.21 & 0.21 & 0.30 & 0.01 \\
\hline $\mathrm{CO}_{2}$ & n.d. & n.d. & 0.03 & 0.53 & 0.09 & 0.03 & 0.2 & 0.27 \\
\hline $\mathrm{F}$ & 0.022 & 0.029 & 0.060 & 0.042 & 1.380 & 0.070 & 0.082 & 0.019 \\
\hline $\mathrm{O}=\mathrm{F}$ & -0.011 & -0.013 & -0.026 & -0.018 & -0.581 & -0.030 & -0.035 & -0.008 \\
\hline Sum & 99.0 & 99.9 & 100.0 & 99.8 & 99.9 & 98.2 & 100.1 & 100.1 \\
\hline \multicolumn{9}{|c|}{ Trace elements (ppm) } \\
\hline $\mathrm{Zn}$ & 35 & 65 & 65 & 34 & 120 & 80 & 160 & 54 \\
\hline $\mathrm{Rb}$ & 305 & 229 & 217 & 313 & 933 & 241 & 186 & 329 \\
\hline $\mathrm{Sr}$ & 52 & 117 & 127 & 90 & 94 & 176 & 208 & 56 \\
\hline Y & 46.8 & 35.2 & 40.5 & 26.4 & 46.7 & 34.3 & 37.7 & 22.9 \\
\hline $\mathrm{Zr}$ & 227 & 330 & 367 & 172 & 338 & 309 & 430 & 167 \\
\hline $\mathrm{Nb}$ & 13 & 15 & 16 & $<10$ & 17 & 14 & 13 & $<10$ \\
\hline $\mathrm{Sn}$ & $<=20$ & $<20$ & n.d. & 5 & $<20$ & n.d. & 4 & 7 \\
\hline $\mathrm{Cs}$ & 11.4 & 7.8 & 13.9 & 8.8 & 21.9 & 7.6 & 10.4 & 7.8 \\
\hline $\mathrm{La}$ & 75.2 & 75.9 & 81.6 & 60.4 & 67.4 & 68.9 & 78.4 & 37.7 \\
\hline $\mathrm{Ce}$ & 153 & 149 & 155 & 115 & 138 & 135 & 155 & 72 \\
\hline $\operatorname{Pr}$ & 17.6 & 16.8 & 18.1 & 12.2 & 16.2 & 15.3 & 17.6 & 7.6 \\
\hline $\mathrm{Nd}$ & 61.7 & 59.3 & 63.4 & 41.4 & 57.9 & 54.2 & 63.6 & 26.0 \\
\hline $\mathrm{Sm}$ & 11.9 & 10.6 & 11.2 & 7.0 & 11.3 & 9.7 & 11.3 & 4.8 \\
\hline $\mathrm{Eu}$ & 0.76 & 1.32 & 1.37 & 0.79 & 1.31 & 1.41 & 1.98 & 0.65 \\
\hline $\mathrm{Gd}$ & 10.24 & 8.31 & 9.29 & 5.53 & 9.62 & 8.09 & 9.04 & 4.12 \\
\hline $\mathrm{Tb}$ & 1.55 & 1.242 & 1.35 & 0.83 & 1.50 & 1.16 & 1.27 & 0.64 \\
\hline Dy & 9.10 & 7.22 & 7.87 & 4.74 & 9.17 & 6.72 & 7.46 & 3.86 \\
\hline Ho & 1.71 & 1.36 & 1.48 & 0.92 & 1.75 & 1.27 & 1.45 & 0.77 \\
\hline $\mathrm{Er}$ & 4.88 & 3.87 & 4.26 & 2.65 & 5.04 & 3.61 & 4.06 & 2.32 \\
\hline $\mathrm{Tm}$ & 0.66 & 0.53 & 0.58 & 0.39 & 0.72 & 0.49 & 0.55 & 0.34 \\
\hline $\mathrm{Yb}$ & 4.23 & 3.52 & 3.75 & 2.56 & 4.77 & 3.23 & 3.71 & 2.38 \\
\hline $\mathrm{Lu}$ & 0.61 & 0.53 & 0.55 & 0.37 & 0.68 & 0.49 & 0.56 & 0.36 \\
\hline Hf & 7.05 & 8.69 & 9.62 & 5.75 & 8.49 & 7.97 & 9.99 & 5.49 \\
\hline $\mathrm{Pb}$ & 40.1 & 30.4 & 32.3 & 28.3 & 38.4 & 30.1 & 43.2 & 50.2 \\
\hline $\mathrm{Th}$ & 43.5 & 25.2 & 26.6 & 27.5 & 20.6 & 22.7 & 24.2 & 22.7 \\
\hline $\mathrm{U}$ & 8.4 & 4.9 & 6.2 & 8.0 & 4.7 & 5.2 & 5.1 & 7.2 \\
\hline $\mathrm{Be}$ & 3.8 & 4.0 & 3.8 & n.d. & 31 & 3.7 & n.d. & n.d. \\
\hline $\mathrm{Co}$ & $<5$ & 7 & 8 & n.d. & 9 & 11 & n.d. & n.d. \\
\hline $\mathrm{Cr}$ & $<20$ & $<20$ & $<20$ & 39 & $<20$ & $<20$ & 34 & 32 \\
\hline $\mathrm{Cu}$ & $<5$ & $<5$ & $<5$ & n.d. & $<5$ & 7 & n.d. & n.d. \\
\hline $\mathrm{Li}$ & 23 & 24 & 51 & n.d. & 179 & 32 & n.d. & n.d. \\
\hline $\mathrm{Ni}$ & $<=20$ & $<20$ & $<20$ & $<10$ & $<20$ & n.d. & $<10$ & $<10$ \\
\hline $\mathrm{Sc}$ & 4 & 7 & 7 & n.d. & 11 & 9 & n.d. & n.d. \\
\hline V & 40 & 85 & 95 & $<10$ & 165 & 180 & 27 & $<10$ \\
\hline $\mathrm{Zr} / \mathrm{Hf}$ & 32.3 & 38.0 & 38.1 & 29.9 & 39.8 & 38.7 & 43.0 & 30.4 \\
\hline Y/Ho & 27.4 & 26.0 & 27.3 & 28.7 & 26.7 & 27.0 & 26.0 & 29.6 \\
\hline $\mathrm{Th} / \mathrm{U}$ & 5.17 & 5.18 & 4.33 & 3.45 & 4.36 & 4.37 & 4.77 & 3.14 \\
\hline
\end{tabular}




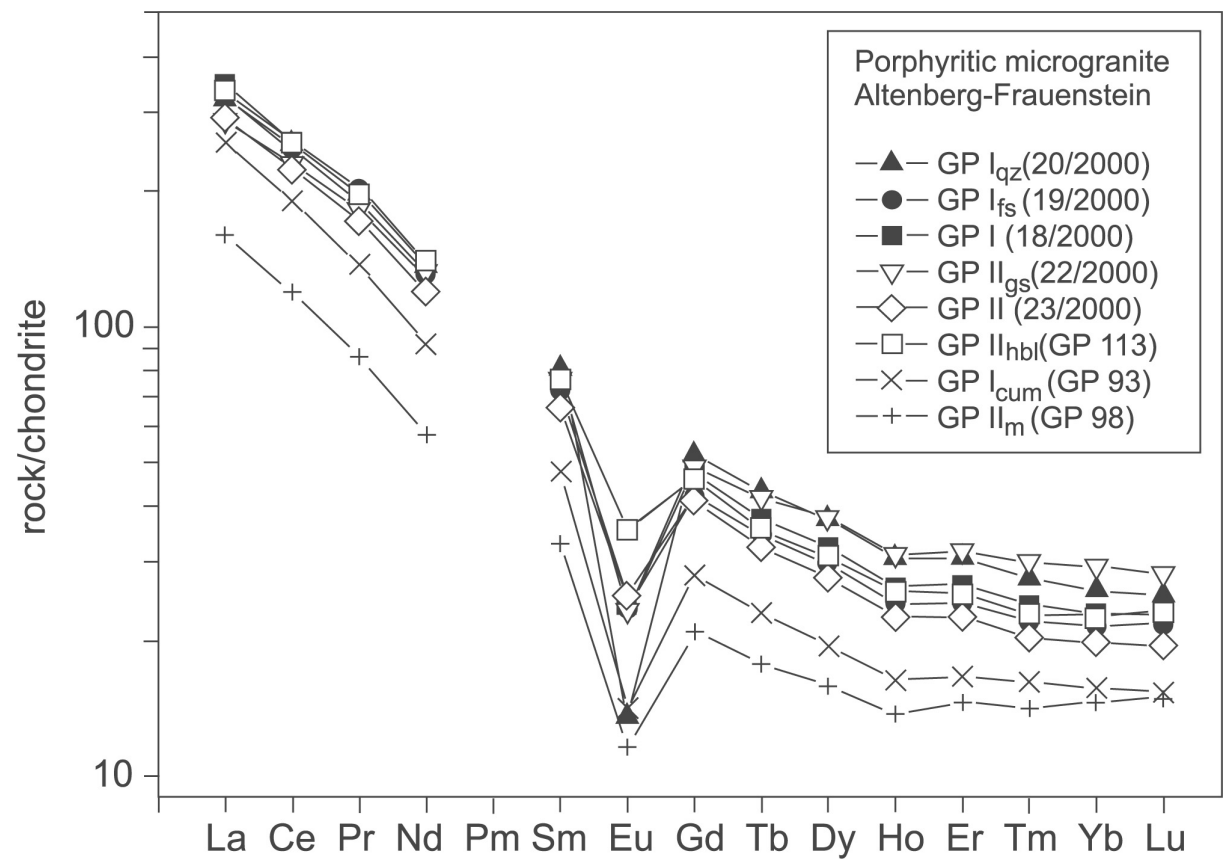

Fig. 8. Chondrite-normalized REE distribution patterns of characteristic samples of the main varieties of the porphyritic microgranite of Altenberg-Frauenstein.

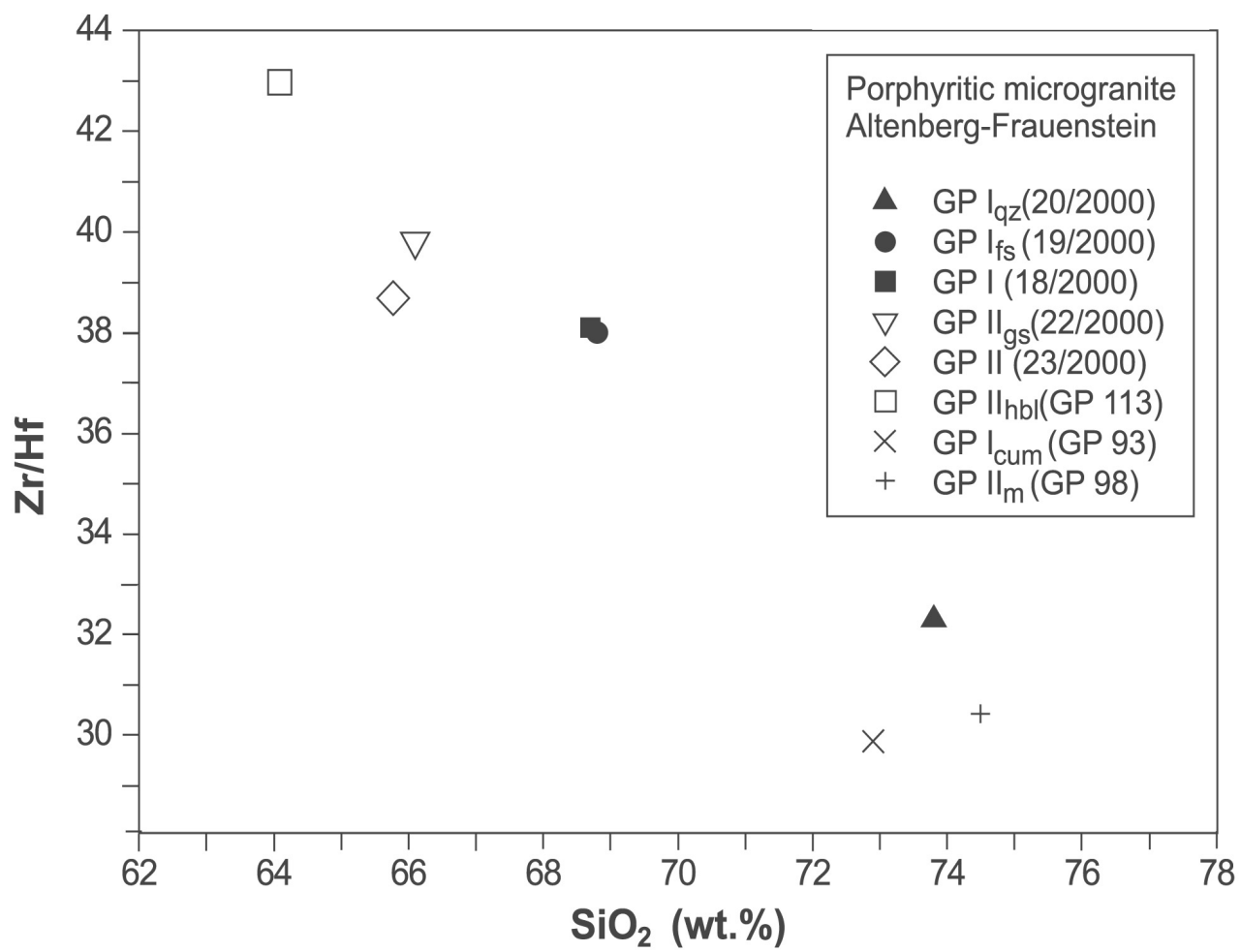

Fig. 9. $\mathrm{Zr} / \mathrm{Hf}$ versus $\mathrm{SiO}_{2}$ plot for characteristic samples of the main varieties of the porphyritic microgranite of Altenberg-Frauenstein. 

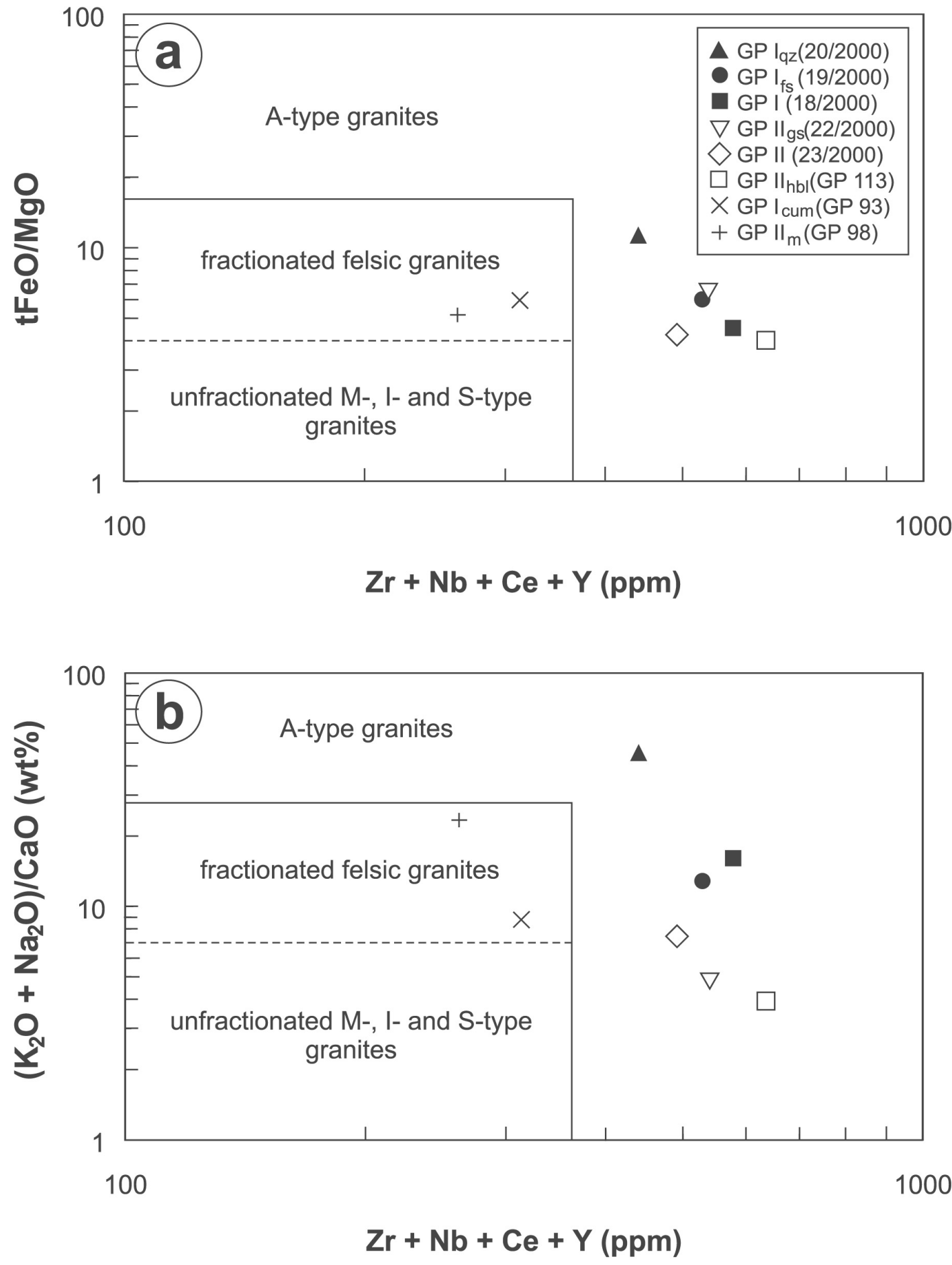

Fig. 10. $\mathrm{Zr}+\mathrm{Nb}+\mathrm{Ce}+\mathrm{Y}$ versus $t \mathrm{FeO} / \mathrm{MgO}(a)$ and $\left(\mathrm{K}_{2} \mathrm{O}+\mathrm{Na}_{2} \mathrm{O}\right) / \mathrm{CaO}$ plots (b) after Whalen et al. (1987) for characteristic samples of the main varieties of the porphyritic microgranite of Altenberg-Frauenstein. The diagram shows fields for A-type granites and also for fractionated felsic granites and unfractionated $M$-, I- and $S$ type granites. 


\section{Feldspar}

K-feldspar and plagioclase occur in two generations (Fig. 11). The first K-feldspar generation occurs as euhedral phenocrysts, some of which are mantled by plagioclase, and the second is a major constituent in the groundmass. From the core $\left(\mathrm{An}_{0} \mathrm{Ab}_{2} \mathrm{Or}_{98}\right)$ of the phenocrysts to the margin $\left(\mathrm{An}_{2} \mathrm{Ab}_{40} \mathrm{Or}_{58}\right)$ the contents of total $\mathrm{FeO}(\mathrm{tFeO})$ increase, while $\mathrm{BaO}$ and $\mathrm{SrO}$ decrease (Table 3; Fig. 12). The composition of the matrix K-feldspar exhibits an opposite trend and ranges from $\mathrm{An}_{1} \mathrm{Ab}_{30} \mathrm{Or}_{69}$ to $\mathrm{An}_{0} \mathrm{Ab}_{2} \mathrm{Or}_{98}$ with constant $\mathrm{SrO}$. A number of the K-feldspar phenocrysts contain subhedral to euhedral inclusions of oligoclase $\left(\mathrm{An}_{26}-\right.$ $\left.A n_{29}\right)$. Some of the K-feldspar phenocrysts are mantled by oligoclase $\left(\mathrm{An}_{26}-\mathrm{An}_{30}\right)$ which is typical of rapakivi granites. Fig. 12a shows a trace element profile of a mantled $\mathrm{K}$-feldspar. $\mathrm{SrO}$ de- creases from core to rim while $\mathrm{tFeO}$ continuously increases in K-feldspar as well as in plagioclase. The $\mathrm{SrO}$ of the K-feldspar correlates negatively with $\mathrm{Na}_{2} \mathrm{O}$ content (Fig. 12b). Element maps of a mantled K-feldspar, made by scanning the phenocrysts with the beam of the electron microprobe, show a zoned euhedral K-feldspar with oligoclase inclusions and with a mantle of strongly albitized oligoclase (Fig. 13). Plagioclase of similar composition forms ovoid to euhedral sieve-textured phenocrysts with biotite, epidote, titanomagnetite, and quartz inclusions (Fig. 4c). Another type of euhedral plagioclase phenocryst (up to 2 $\mathrm{cm}$ in size) consists of an andesine core $\left(\mathrm{An}_{36} \mathrm{Ab}_{58} \mathrm{Or}_{6}\right)$ mantled by an oligoclase rim $\left(\mathrm{An}_{27} \mathrm{Ab}_{64} \mathrm{Or}_{9}\right.$; Fig. 14). The composition of the rim corresponds to the composition of the plagioclase mantle around K-feldspars. Plagioclases with
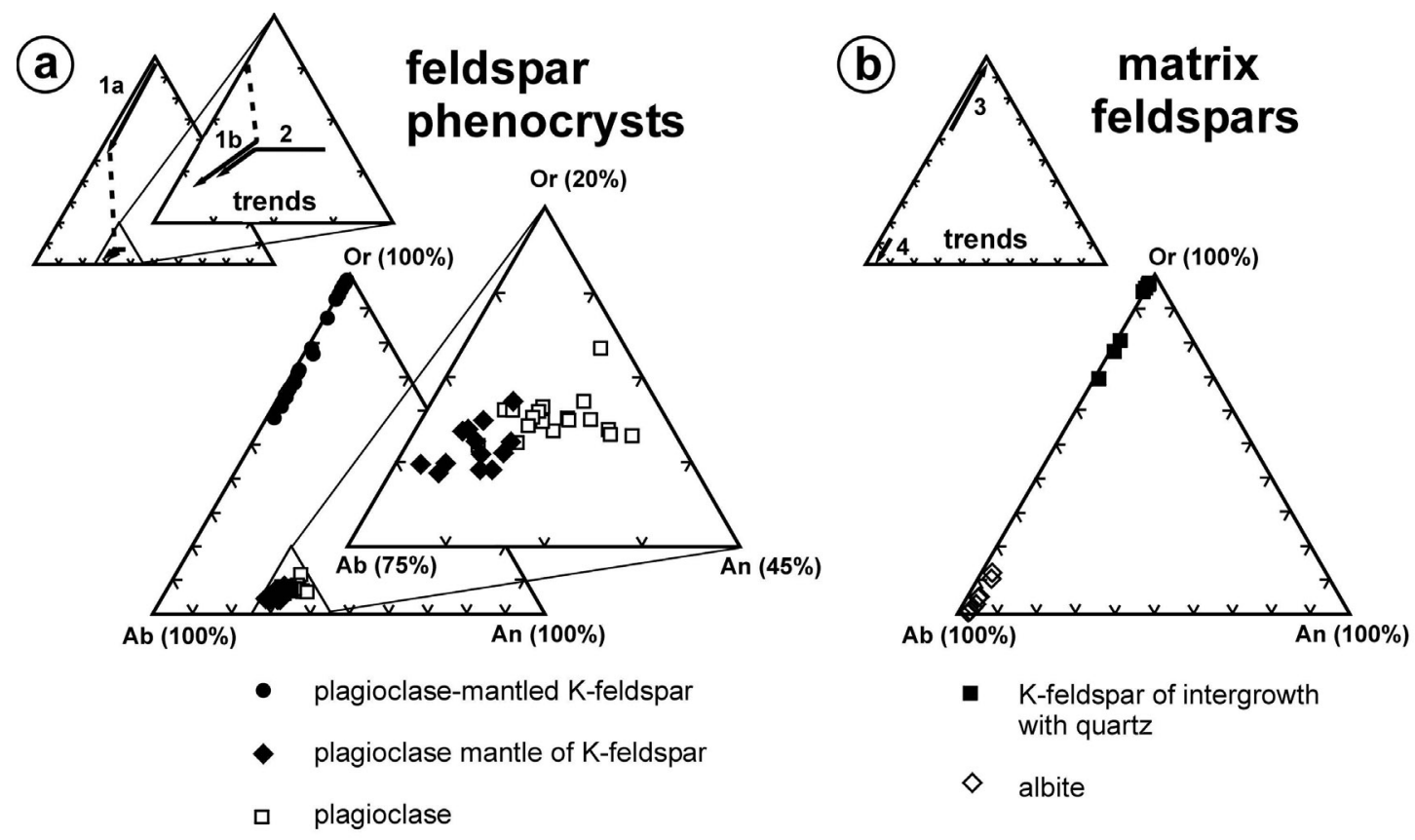

Fig. 11. Ternary diagrams showing mol\% of feldspar components (Or, Orthoclase; An, Anorthite; Ab, Albite) in phenocrystic and matrix feldspars and their trends with progressing crystallisation. The $K$-feldspar phenocrysts (1a) started to grow with an $\mathrm{An} n_{0} \mathrm{Ab}_{2} \mathrm{Or}_{98}$ composition which changes to an $\mathrm{A} n_{2} \mathrm{~A} b_{40} \mathrm{Or} r_{58}$ composition. Some of the $K$-feldspar phenocrysts are mantled by an oligoclase rim (1b) starting with $A n_{26}$ and ending with $A n_{30}$. The core of the plagioclase phenocrysts (2) is of andesine composition and the rim show the same oligoclase trend like the rapakivi feldspar mantles. The K-feldspar of the matrix (4) shows the opposite trend to the K-feldspar phenocrysts. 

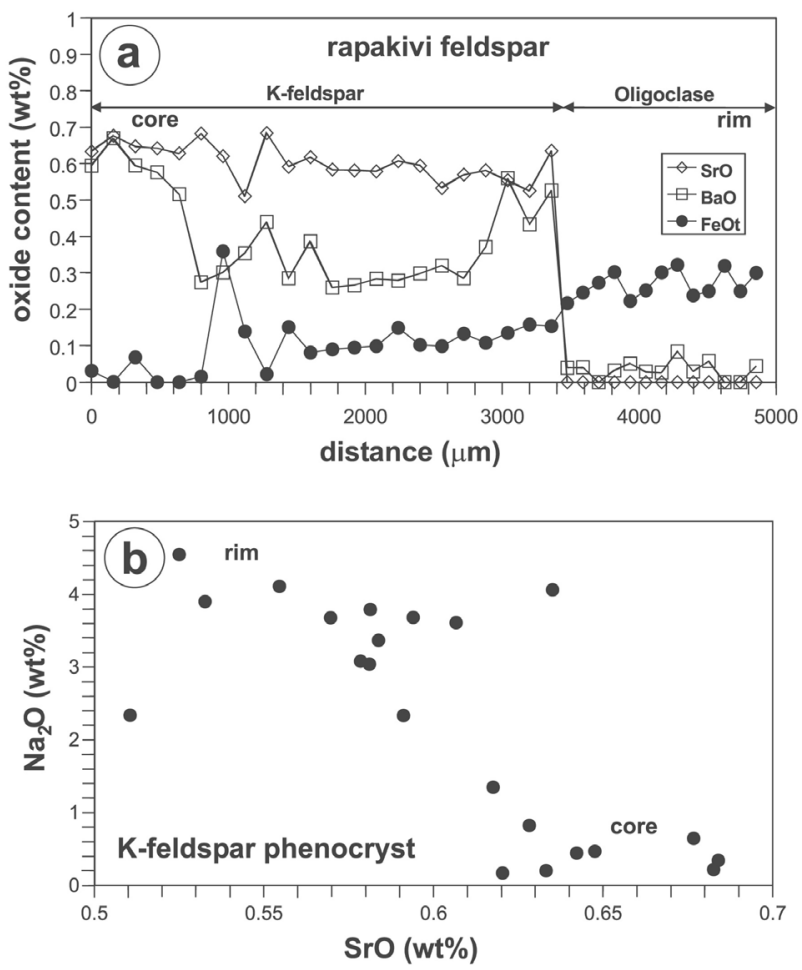

Fig. 12. Minor elements of mantled K-feldspar. $a-$ tFeO, $\mathrm{SrO}$, and $\mathrm{BaO}$ distribution in the rapakivi feldspar. Note the high $\mathrm{BaO}$ and $\mathrm{SrO}$ in the core. $b$ $-\mathrm{Na}_{2} \mathrm{O}$ versus $\mathrm{SrO}$ plot. The negative trend of the $\mathrm{Na}_{2} \mathrm{O} / \mathrm{SrO}$ ratio may indicate a continuous pressure decrease during the growth of the K-feldspar phenocryst.

Table 3. Representative electron microprobe analysis of $K$-feldspar, plagioclase and albite (number of spots in parentheses). For $\mathrm{SrO}$ an overlap correction was carried out ( $\left.\mathrm{SrO} \cdot 0.0062 \mathrm{per} \mathrm{SiO}_{2} w t \%\right)$.

\begin{tabular}{|c|c|c|c|c|c|c|c|c|}
\hline & \multicolumn{2}{|c|}{$\begin{array}{l}\text { plagioclase } \\
\text { phenocryst }\end{array}$} & \multicolumn{3}{|c|}{ mantled K-feldspar } & \multicolumn{2}{|c|}{ matrix K-feldspar } & \multirow{2}{*}{$\begin{array}{l}\begin{array}{l}\text { matrix } \\
\text { albite }\end{array} \\
(8)\end{array}$} \\
\hline & $\begin{array}{l}\text { core } \\
(11)\end{array}$ & $\begin{array}{l}\text { rim } \\
(9)\end{array}$ & $\begin{array}{l}\text { kfs core } \\
\text { (7) }\end{array}$ & $\begin{array}{l}\text { kfs rim } \\
(8)\end{array}$ & $\begin{array}{l}\text { pl rim } \\
\text { (13) }\end{array}$ & $\begin{array}{l}\text { core } \\
\text { (3) }\end{array}$ & $\begin{array}{l}\text { rim } \\
(5)\end{array}$ & \\
\hline \multicolumn{9}{|c|}{ major elements (wt $\%$ ) } \\
\hline $\mathrm{SiO}_{2}$ & 58.90 & 59.58 & 62.92 & 64.74 & 60.03 & 64.35 & 63.61 & 66.09 \\
\hline $\mathrm{Al}_{2} \mathrm{O}_{3}$ & 24.14 & 23.63 & 17.98 & 18.24 & 23.38 & 18.24 & 17.73 & 19.94 \\
\hline $\mathrm{tFeO}$ & 0.29 & 0.28 & 0.07 & 0.13 & 0.27 & 0.07 & 0.09 & 0.47 \\
\hline $\mathrm{CaO}$ & 6.83 & 6.22 & 0.0 & 0.30 & 5.94 & 0.23 & 0.02 & 0.73 \\
\hline $\mathrm{Na}_{2} \mathrm{O}$ & 6.72 & 7.24 & 0.42 & 3.92 & 7.58 & 2.66 & 0.37 & 10.65 \\
\hline $\mathrm{K}_{2} \mathrm{O}$ & 1.34 & 1.22 & 16.23 & 10.85 & 1.00 & 13.13 & 16.70 & 0.83 \\
\hline $\mathrm{BaO}$ & 0.09 & 0.07 & 0.50 & 0.38 & 0.03 & n.d. & n.d. & n.d. \\
\hline $\mathrm{SrO}$ & 0.0 & 0.0 & 0.65 & 0.57 & 0.0 & 0.44 & 0.42 & 0.42 \\
\hline Sum & 98.31 & 98.24 & 98.77 & 99.13 & 98.5 & 99.52 & 99.33 & 99.54 \\
\hline \multicolumn{9}{|c|}{ end-members in mole $\%$} \\
\hline Or & 7.8 & 7.0 & 96.2 & 63.6 & 5.7 & 75.7 & 96.6 & 4.8 \\
\hline $\mathrm{Ab}$ & 59.0 & 63.1 & 3.8 & 34.9 & 65.8 & 23.2 & 3.3 & 91.7 \\
\hline An & 33.2 & 29.9 & 0.0 & 1.5 & 28.5 & 1.1 & 0.1 & 3.5 \\
\hline \multicolumn{9}{|c|}{ trace elements (ppm) } \\
\hline $\mathrm{Ti}$ & 115 & 181 & 116 & 89 & 112 & 170 & 50 & 99 \\
\hline $\mathrm{Mn}$ & 74 & 8 & 114 & 114 & 99 & 23 & 78 & 176 \\
\hline $\mathrm{Mg}$ & 75 & 31 & 24 & 9 & 15 & 0 & 0 & 364 \\
\hline $\mathrm{P}$ & 67 & 20 & 40 & 94 & 50 & 40 & 44 & 45 \\
\hline
\end{tabular}

n.d. $=$ not detected 

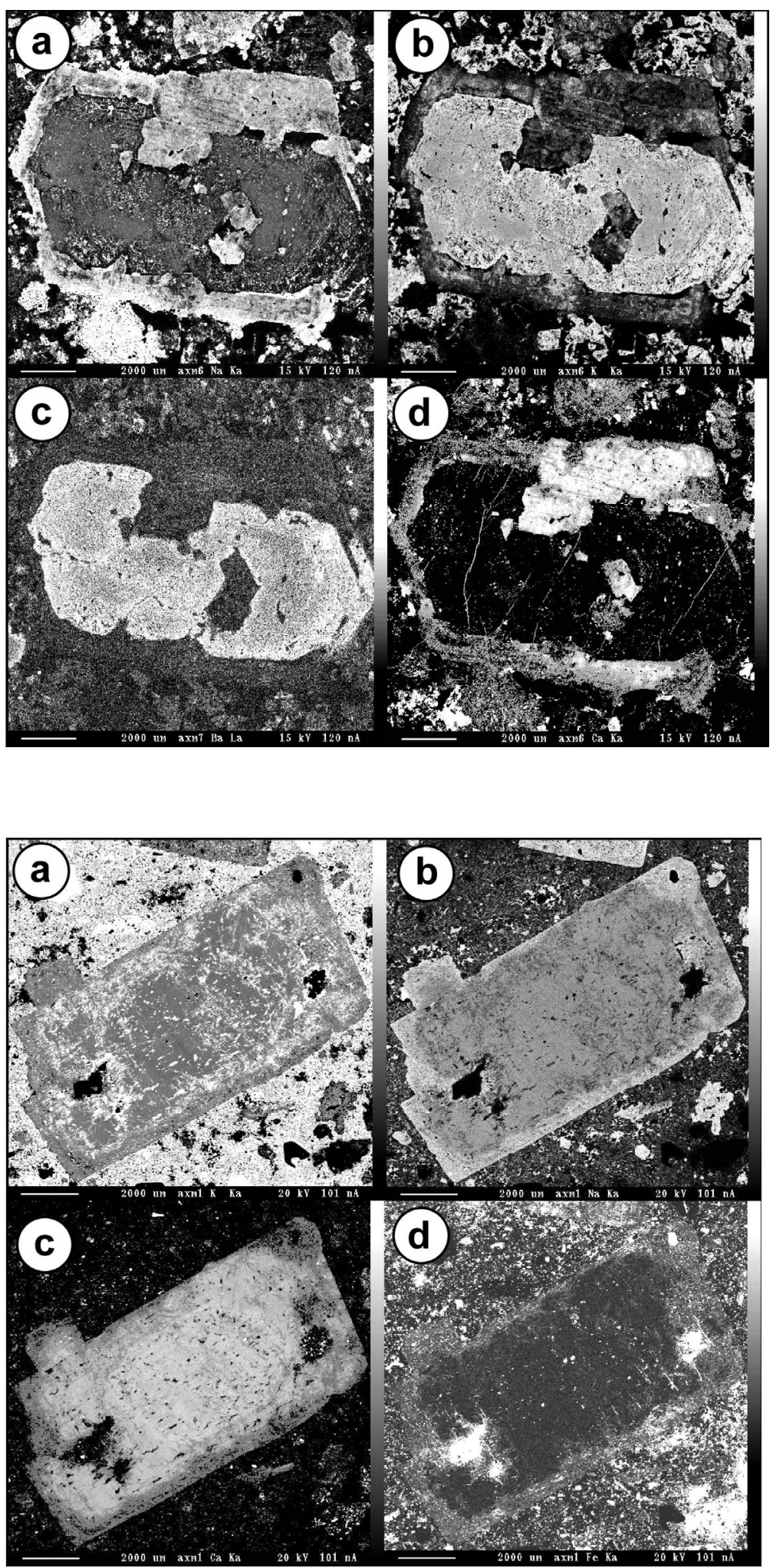

Fig. 13. Element maps of mantled $K$-feldspar for $\mathrm{Na}(a), \mathrm{K}(\mathrm{b}), \mathrm{Ba}(\mathrm{c})$ and $\mathrm{Ca}(d)$. The Ca image shows the oligoclase mantle around $K$ feldspar whilst the Na image shows albitization starting at the rim and overprints older magmatic zoning. Inclusions of subeuhedral andesines $(b, c)$ are well contrasted.
Fig. 14. Element maps of plagioclase phenocryst for $\mathrm{K}(\mathrm{a}), \mathrm{Na}$ (b), $\mathrm{Ca}(c)$ and $\mathrm{Fe}(d)$. The images show internal zonation of the plagioclase core with andesine composition (c), the influence of sericitisation (a), marginal albitization (b) and hematitisation (d), particularly of the oligoclase rim. 
andesine cores are common in the mafic varieties of GP II.

The youngest feldspar generation is represented by subhedral, strongly saussuritized albites, $0.1-0.5 \mathrm{~mm}$ in size. The average composition of the albites is $\mathrm{An}_{3} \mathrm{Ab}_{92} \mathrm{Or}_{5}$ with high tFeO. Furthermore, a widespread late magmatic albitization of the older plagioclase generations is present (Figs. 11 and 12). Alteration mobilised Fe-oxides from the rock which causes the characteristic red-brown coloring of the albite crystals and rims of the phenocrysts.

\section{Amphibole}

The euhedral hornblende grains of GP II embedded in fine-grained biotite and epidote are slightly zoned ferro-tremolites with high $\mathrm{tFe} /(\mathrm{Mg}+\mathrm{tFe})$ between 0.67 and 0.77 (Table 4). They exhibit a slight change in $\mathrm{Fe}$-enrichment, both $\mathrm{Fe}^{2+}$ relative to $\mathrm{Mg}$ and $\mathrm{Fe}^{3+}$ relative to $\mathrm{Al}^{\mathrm{VI}}$, during crystallisation. There is a noticeable decrease of $\mathrm{Ti}$ in the outer rim. Temperatures derived from the amphibole-plagioclase thermometer (Holland \& Blundy 1994) suggest an average crystallisation temper-

Table 4. Representative electron microprobe analysis of hornblende (wt\%) and cation calculation after Blundy and Holland (1994).

\begin{tabular}{|c|c|c|c|c|c|c|c|c|c|c|}
\hline & core 01 & core 02 & core 03 & core 04 & core 05 & $\operatorname{rim} 01$ & $\operatorname{rim} 02$ & $\operatorname{rim} 03$ & rim04 & rim05 \\
\hline $\mathrm{SiO}_{2}$ & 42.68 & 43.02 & 43.04 & 42.88 & 42.94 & 42.05 & 41.99 & 43.61 & 43.16 & 42.96 \\
\hline $\mathrm{TiO}_{2}$ & 1.64 & 1.52 & 1.5 & 1.51 & 1.52 & 1.56 & 1.43 & 1.34 & 1.39 & 1.26 \\
\hline $\mathrm{Al}_{2} \mathrm{O}_{3}$ & 6.97 & 7.16 & 7.08 & 7.05 & 7.03 & 7.14 & 7.39 & 6.8 & 6.89 & 6.76 \\
\hline $\mathrm{tFeO}$ & 24.81 & 25.21 & 25.7 & 25.74 & 26.14 & 27 & 27.92 & 26.88 & 26.77 & 26.45 \\
\hline $\mathrm{MnO}$ & 0.27 & 0.3 & 0.27 & 0.28 & 0.33 & 0.32 & 0.44 & 0.3 & 0.38 & 0.29 \\
\hline $\mathrm{MgO}$ & 6.75 & 6.61 & 6.5 & 6.37 & 6.02 & 5.25 & 4.75 & 5.73 & 5.69 & 5.89 \\
\hline $\mathrm{CaO}$ & 10.19 & 10.09 & 10.16 & 10.17 & 10.1 & 9.96 & 9.91 & 9.81 & 9.73 & 9.74 \\
\hline $\mathrm{Na}_{2} \mathrm{O}$ & 1.88 & 1.85 & 1.93 & 1.86 & 1.87 & 1.88 & 1.92 & 1.8 & 1.88 & 1.86 \\
\hline $\mathrm{K}_{2} \mathrm{O}$ & 1.00 & 1.06 & 1.05 & 1.09 & 1.08 & 1.09 & 1.04 & 0.85 & 0.89 & 0.92 \\
\hline Sum & 96.19 & 96.10 & 97.23 & 96.95 & 97.03 & 96.25 & 96.79 & 97.12 & 96.78 & 96.13 \\
\hline $\mathrm{FeO}_{\text {calc }}$ & 2.32 & 3.28 & 2.70 & 2.67 & 2.96 & 2.84 & 3.46 & 4.07 & 3.73 & 3.53 \\
\hline $\mathrm{Fe}_{2} \mathrm{O}_{3 \text { calc }}$ & 22.72 & 22.25 & 23.27 & 23.34 & 23.48 & 24.44 & 24.81 & 23.22 & 23.41 & 23.27 \\
\hline $\mathrm{H}_{2} \mathrm{O}_{\text {calc }}$ & 1.88 & 1.90 & 1.90 & 1.89 & 1.89 & 1.86 & 1.87 & 1.89 & 1.88 & 1.87 \\
\hline $\begin{array}{l}\text { Sum } \\
\text { cations }\end{array}$ & 98.31 & 99.05 & 99.40 & 99.11 & 99.22 & 98.40 & 99.00 & 99.42 & 99.04 & 98.36 \\
\hline $\mathrm{Si}$ & 6.749 & 6.745 & 6.748 & 6.747 & 6.758 & 6.715 & 6.686 & 6.829 & 6.799 & 6.811 \\
\hline $\mathrm{Ti}$ & 0.195 & 0.179 & 0.177 & 0.179 & 0.18 & 0.187 & 0.171 & 0.158 & 0.165 & 0.15 \\
\hline $\mathrm{Al}$ & 1.299 & 1.323 & 1.309 & 1.308 & 1.304 & 1.344 & 1.387 & 1.255 & 1.28 & 1.263 \\
\hline $\mathrm{Fe}^{3+}$ & 0.277 & 0.386 & 0.318 & 0.31 & 0.35 & 0.338 & 0.414 & 0.477 & 0.442 & 0.419 \\
\hline $\mathrm{Fe}^{2+}$ & 3.005 & 2.92 & 3.052 & 3.077 & 3.09 & 3.268 & 3.304 & 3.043 & 3.084 & 3.088 \\
\hline $\mathrm{Mn}$ & 0.036 & 0.04 & 0.036 & 0.037 & 0.044 & 0.043 & 0.059 & 0.04 & 0.051 & 0.039 \\
\hline $\mathrm{Mg}$ & 1.591 & 1.544 & 1.519 & 1.494 & 1.412 & 1.25 & 1.127 & 1.337 & 1.336 & 1.392 \\
\hline $\mathrm{Ca}$ & 1.727 & 1.695 & 1.707 & 1.715 & 1.703 & 1.704 & 1.691 & 1.646 & 1.642 & 1.655 \\
\hline $\mathrm{Na}$ & 0.576 & 0.562 & 0.587 & 0.567 & 0.571 & 0.582 & 0.593 & 0.547 & 0.574 & 0.572 \\
\hline $\mathrm{K}$ & 0.202 & 0.212 & 0.21 & 0.219 & 0.217 & 0.222 & 0.211 & 0.17 & 0.179 & 0.186 \\
\hline Sum & 15.657 & 15.608 & 15.661 & 15.657 & 15.629 & 15.657 & 15.644 & 15.504 & 15.552 & 15.576 \\
\hline Fe\# & 0.673 & 0.682 & 0.689 & 0.694 & 0.709 & 0.743 & 0.767 & 0.725 & 0.725 & 0.716 \\
\hline \multicolumn{11}{|c|}{ pressure and temperature calculation } \\
\hline $\mathrm{p}(\mathrm{kbar})^{1}$ & 3.18 & 3.29 & 3.22 & 3.22 & 3.20 & 3.39 & 3.59 & 2.97 & 3.08 & 3.00 \\
\hline & average & core $^{1}=3$. & $0.7 \mathrm{kbar}$ & & & average & $\mathrm{p}_{\text {rim }}{ }^{1}=3$ & 0.9 kbar & & \\
\hline \multicolumn{11}{|c|}{ rim composition of coexisting oligoclase } \\
\hline Xab & 0.655 & 0.655 & 0.645 & 0.656 & 0.679 & 0.661 & 0.685 & 0.689 & 0.626 & 0.657 \\
\hline Xan & 0.234 & 0.300 & 0.301 & 0.277 & 0.273 & 0.274 & 0.274 & 0.263 & 0.290 & 0.291 \\
\hline $\mathrm{T}\left({ }^{\circ} \mathrm{C}\right)^{2}$ & 759.5 & 791.0 & 787.8 & 775.7 & 778.5 & 783.6 & 784.8 & 771.9 & 795.3 & 786.5 \\
\hline \multirow[t]{2}{*}{$\mathrm{p}(\mathrm{kbar})^{3}$} & 2.05 & 1.49 & 1.51 & 1.76 & 1.69 & 1.74 & 1.89 & 1.62 & 1.22 & 1.35 \\
\hline & & & & & & averaø & $\operatorname{rim}^{3}=1$ & $0.9 \mathrm{kbar}$ & & \\
\hline
\end{tabular}

${ }^{1}$ Results based on the Al-in-hornblende barometer after Schmidt (1992)

${ }^{2}$ Results based on the hornblende plagioclase thermometry calibration reaction edenite + albite $=$ richterite + anorthite after Holland and Blundy (1994)

${ }^{3}$ Results based on iterations of the Al-in-hornblende barometer after Anderson and Smith (1995) using the hornblende plagioclase thermometer of Holland and Blundy (1994)

$\mathrm{Fe} \#=\mathrm{tFe} /(\mathrm{Mg}+\mathrm{tFe})$ 
ature of $781 \pm 10^{\circ} \mathrm{C}$ using the calibration reaction edenite + albite $=$ richterite + anorthite. Utilizing $\mathrm{Al}$ in the amphibole barometers of Schmidt (1992) and Anderson and Smith (1995), pressure estimates are 3.2 $\pm 0.9 \mathrm{kbar}$ and $1.6 \pm 0.9 \mathrm{kbar}$, respectively.

\section{Biotite}

The phenocrystic biotite with greenish brown color and with common inclusions of accessory minerals is mostly altered to chlorite and epidote. Unaltered Li- and Al-poor biotites in GP I and GP II exhibit a compositional zoning with tFe/ $(\mathrm{Mg}+\mathrm{tFe}) 0.67-0.70$ in the core and $0.73-0.75$ in the rim (Table 5). The biotites, with $\mathrm{tFe}+\mathrm{Mg}+\mathrm{Ti}-$ $\mathrm{Al}^{\mathrm{VI}}>4$ and with $\mathrm{Mg}-\mathrm{Li}$ between 1.4 and 1.9, plot in the annite field (after Tischendorf et al. 1997), which is typical of rapakivi granites (Velikoslavinsky 1994, Elliott 2001). The original composition of fine-grained biotite could not be determined because it is converted to epidote and chlorite.

\section{PETROLOGICAL CONSIDERATIONS}

The formation of plagioclase mantles around Kfeldspar phenocrysts is related to changes in physicochemical conditions ( $\mathrm{P}, \mathrm{T}$, composition) in the magma which stabilized plagioclase instead of $\mathrm{K}$ feldspar, allowing plagioclase to nucleate on Kfeldspar crystals. Experimental studies and petrographic observations indicate that the two most realistic mechanisms are 1) mixing of two magmas of different compositon (Hibbard 1981, Wark \& Stimac 1992), and 2) crystallisation of granite melt under conditions involving a marked decrease of pressure combined with a small change in temperature (Nekvasil 1991, Eklund \& Shebanov 1999).

Besides the plagioclase-mantled K-feldspar, the occurrence of sieve-textured plagioclase and resorbed (rounded) quartz crystals mantled by microcrystalline plagioclase, biotite, and titanomagnetite indicate a textural adjustment of pre-mixing crystals (early phenocrysts) that are suddenly placed in an environment in which they are far out
Table 5. Representative electron microprobe analysis of biotite (wt\%). $\mathrm{Li}_{2} \mathrm{O}_{\text {calc }}$ is calculated after Tischendorf et al. (1997).

\begin{tabular}{|c|c|c|c|c|c|}
\hline & core 01 & core 02 & core 03 & $\operatorname{rim} 01$ & $\operatorname{rim} 02$ \\
\hline $\mathrm{SiO}_{2}$ & 34.51 & 35.02 & 35.37 & 34.52 & 32.53 \\
\hline $\mathrm{TiO}_{2}$ & 3.36 & 2.92 & 2.30 & 1.74 & 1.01 \\
\hline $\mathrm{Al}_{2} \mathrm{O}_{3}$ & 11.51 & 11.46 & 11.06 & 11.51 & 13.11 \\
\hline $\mathrm{MgO}$ & 6.73 & 7.11 & 7.36 & 5.86 & 6.49 \\
\hline $\mathrm{CaO}$ & 0.05 & 0.19 & 0.07 & 0.01 & 0.08 \\
\hline $\mathrm{MnO}$ & 0.26 & 0.25 & 0.24 & 0.37 & 0.41 \\
\hline $\mathrm{tFeO}$ & 28.34 & 28.02 & 27.13 & 31.53 & 31.64 \\
\hline $\mathrm{Na}_{2} \mathrm{O}$ & 0.12 & 0.17 & 0.14 & 0.07 & 0.05 \\
\hline $\mathrm{K}_{2} \mathrm{O}$ & 8.26 & 8.34 & 8.44 & 8.06 & 5.83 \\
\hline $\mathrm{Li}_{2} \mathrm{O}_{\text {calc }}$ & 0.32 & 0.46 & 0.56 & 0.32 & 0.00 \\
\hline $\mathrm{Rb}_{2} \mathrm{O}$ & 0.23 & 0.31 & 0.42 & 0.06 & 0.07 \\
\hline $\mathrm{Cs}_{2} \mathrm{O}$ & 0.12 & 0.10 & 0.18 & 0.00 & 0.09 \\
\hline $\mathrm{F}$ & 0.92 & 1.00 & 1.08 & 0.80 & 0.58 \\
\hline $\mathrm{Cl}$ & 0.39 & 0.42 & 0.44 & 0.74 & 0.57 \\
\hline Sum & 95.12 & 95.77 & 94.79 & 95.58 & 92.46 \\
\hline$-\mathrm{O}=\mathrm{F}$ & 0.39 & 0.42 & 0.46 & 0.34 & 0.24 \\
\hline$-\mathrm{O}=\mathrm{Cl}$ & 0.09 & 0.09 & 0.10 & 0.17 & 0.13 \\
\hline $\begin{array}{l}\text { Sum } \\
\text { cations }\end{array}$ & 94.64 & 95.26 & 94.23 & 95.08 & 92.09 \\
\hline $\mathrm{Si}$ & 5.64 & 5.68 & 5.78 & 5.70 & 5.50 \\
\hline $\mathrm{Ti}$ & 0.41 & 0.36 & 0.28 & 0.22 & 0.13 \\
\hline $\mathrm{A} l^{\mathrm{IV}}$ & 2.36 & 2.32 & 2.22 & 2.30 & 2.50 \\
\hline $\mathrm{Al}^{\mathrm{VI}}$ & 0.00 & 0.00 & 0.00 & 0.00 & 0.11 \\
\hline $\mathrm{Mg}$ & 1.64 & 1.72 & 1.80 & 1.44 & 1.64 \\
\hline $\mathrm{Ca}$ & 0.01 & 0.03 & 0.01 & 0.00 & 0.02 \\
\hline $\mathrm{Mn}$ & 0.04 & 0.04 & 0.03 & 0.05 & 0.06 \\
\hline $\mathrm{tFe}$ & 3.88 & 3.80 & 3.71 & 4.35 & 4.47 \\
\hline $\mathrm{Na}$ & 0.04 & 0.05 & 0.04 & 0.02 & 0.02 \\
\hline K & 1.72 & 1.72 & 1.76 & 1.70 & 1.26 \\
\hline $\mathrm{Li}$ & 0.21 & 0.30 & 0.37 & 0.21 & 0.00 \\
\hline $\mathrm{Rb}$ & 0.02 & 0.03 & 0.04 & 0.01 & 0.01 \\
\hline Cs & 0.01 & 0.01 & 0.01 & 0.00 & 0.01 \\
\hline $\mathrm{OH}$ & 3.42 & 3.37 & 3.32 & 3.38 & 3.53 \\
\hline $\mathrm{F}$ & 0.48 & 0.51 & 0.56 & 0.42 & 0.31 \\
\hline $\mathrm{Cl}$ & 0.11 & 0.12 & 0.12 & 0.21 & 0.16 \\
\hline Sum & 19.99 & 20.06 & 20.05 & 20.01 & 19.73 \\
\hline $\mathrm{Fe} \#$ & 0.70 & 0.69 & 0.67 & 0.75 & 0.73 \\
\hline
\end{tabular}

$\mathrm{tFe}=$ total iron as $\mathrm{Fe}^{2+} ; \mathrm{Fe} \#=\mathrm{tFe} /(\mathrm{Mg}+\mathrm{tFe})$

of equilibrium. Resorption of quartz phenocrysts in the silicic magma (Fig. 7) is explained by mixing-related heating. On the other hand, the dendritic character of the sieve-textured plagioclase phenocrysts (Fig. 4c) is in accord with the undercooling experiments of Lofgren (1974) and Swanson (1977), which have shown that such textures develop during rapid crystallisation. We interpret the sieve-textured plagioclase as a result of 
quenching of the mafic magma during mixing.

Nests (globules) of mafic minerals which are not in equilibrium with the silicic host are a further textural indicator of magma mingling and mixing. Similar globular textures are described by Schreiber et al. (1999) in trachytes of Westerwald (Germany). These authors interpret the spherical inclusions to have originated through immiscibility due to viscosity contrast between trachytic host and latitic guest melts. Such partially chloritized mafic nests and schlieren in the microgranite are rich in acicular apatite.

The common occurrence of allanite as a product of mobilisation and reaction at the contact of $\mathrm{Ca}$-rich and Ca-poor magmas is a possible indicator of magma mixing (Mehnert et al. 1945, Rösler \& Bothe 1990). Conditions for allanite formation are provided by coexistence of magmas with different $\mathrm{Ca}$ and $\mathrm{Fe}$ contents, which causes a high $\mathrm{Ca}$ and REE availability in the boundary zone of the contrasting melts. In addition, the presence and stability of allanite may be affected by the high Th/U ratio of the GP magma. The Th/U of GP is significantly higher (like in many $\mathrm{I}_{\mathrm{S}}$-type granitic rocks of the region) than the values of 2 to 3, which are typical of fractionated granitoids.

For the reasons given above we explain the formation of plagioclase-mantled K-feldspar by interaction of felsic and mafic magmas. K-feldspar megacrysts from a felsic magma were introduced into a coexisting mafic magma, causing local undercooling in the portion of magma surrounding the crystals, and resulting in the growth of a plagioclase mantle in a thermally and compositionally equilibrating system. The observations discussed above as evidence for magma mixing cannot fully exclude the possibility that some of the crystals may represent restite mineralogy, at least in portions of the microgranite (U. Andersson, pers. comm.). For example, the composition of plagioclase is not yet fully understood in the framework of the mixing model. There are megacrysts of (1) resorbed orthoclase, (2) oligoclase, and (3) andesine (not resorbed). All three feldspars are commonly, but not consistently, overgrown by oligoclase. The occurrence of andesine cores is interpreted as a relic of a more mafic magma, whereas the oligoclase phenocrysts represent relics of a silicic magma. The oligoclase overgrowths and sieve-textured plagioclases are supposed to have formed because of the mixing event, but oligoclase seems to be too sodic for such an environment and labradorite, or at least andesine, should be expected as overgrowth (Andersson, pers. comm.). Alternatively, these andesines, as well as largely the mafic minerals and possibly also the SrO-rich K-feldspar cores can be interpreted to be restitic, with some magmatic overgrowths formed in the deep magma chamber prior to emplacement. The oligoclase obviously formed in response to decompression.

This argumentation does not explain why only some of the megacrysts show oligoclase rims. The rims are up to $3 \mathrm{~mm}$ thick and show fine-scale, low amplitude oscillatory zoning, which points to a relatively slow growth under more or less constant conditions. The coexistence of mantled Kfeldspar megacrysts and unmantled ones may be related to nucleation and growth processes as well as to local variations in concentrations of plagioclase forming components. Mantles are usually more abundant in more mafic, Ca-rich assemblages. The detailed textural and geochemical investigations of the porphyritic microgranites permit the establishment of a schematic sequence of crystallisation (Fig. 15). Preserved pre-mixing crystals representing the early magmatic stage are divided into a silicic stratum and a mafic stratum. The first is represented by quartz phenocrysts $\left(\mathrm{q}_{1}\right)$, oligoclase $\left(\mathrm{o}_{1}\right)$, K-feldspar phenocrysts $\left(\mathrm{k}_{1}\right)$ with $\mathrm{o}_{1}$ inclusions, and the latter by andesine (an). The negative correlation of $\mathrm{Na}_{2} \mathrm{O}$ and $\mathrm{SrO}$ of the Kfeldspar phenocrysts $\left(\mathrm{k}_{1}\right)$ is assumed to reflect $\mathrm{K}$ feldspar crystallisation due to continuous pressure decrease. High $\mathrm{Sr}$ values reflect high pressure, and $\mathrm{Na}_{2} \mathrm{O}$ saturation indicates pressure release (Smith 1983 and references therein). The consistently low $\mathrm{SrO}$ in the matrix $\mathrm{K}$-feldspar $\left(\mathrm{k}_{3}\right)$ may reflect crystallisation at constant low pressures. This is consistent with observations in many silicate melts that $\mathrm{K}$ is often thermally sensitive (K-feldspar crystallises when temperature decrease dominates over the pressure) and $\mathrm{Na}$ is more sensitive to pressure (albite crystallisation is common in adi- 


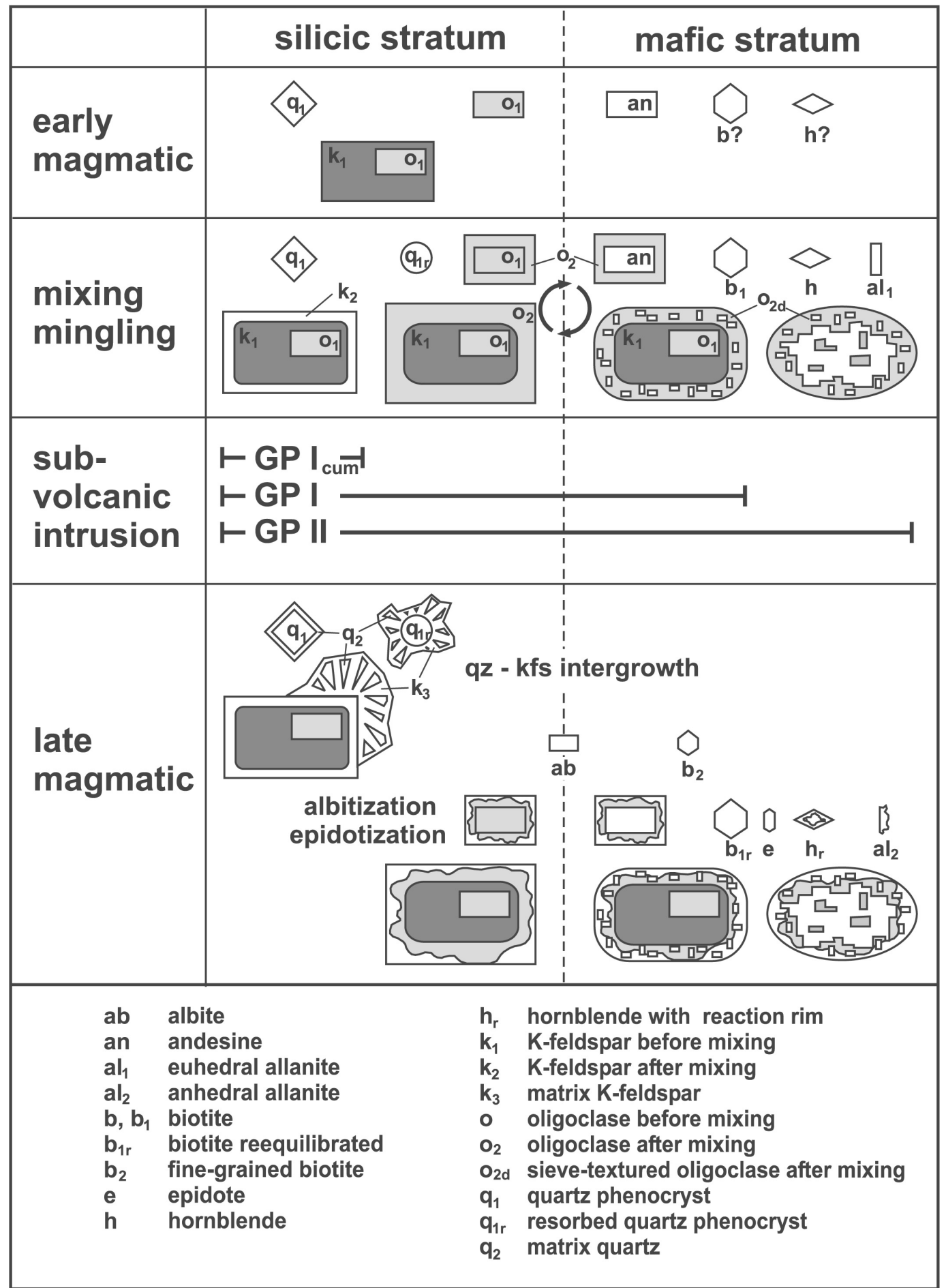

Fig. 15. Interpretative sequence of crystallisation. The textural variety of minerals found in the intrusion stages GP $I_{\text {cum }}, G P I$ and GP II is indicated by bars. 
abatic systems with quench effects; see Nekvasil 1991). The mixing-mingling stage first causes the resorption (rounding) of pre-mixing crystals $\left(\mathrm{q}_{1 \mathrm{r}}\right)$ and second the formation of new crystals due to equilibration $\left(\mathrm{b}_{1}, \mathrm{~h}, \mathrm{al}_{1}\right)$ some of them mantling the pre-existing crystals $\left(\mathrm{O}_{2}\right)$. The formation of sievetextured plagioclase phenocrysts $\left(\mathrm{O}_{2 \mathrm{~d}}\right)$ is explained as a result of rapid textural adjustment in the contact of silicic and mafic magmas causing strong local undercooling. Different crystal habits and textural relationships of the allanite indicate two stages of allanite crystallisation: an early crystallisation which may be associated with magma mixing $\left(\mathrm{al}_{1}\right)$ and a late-magmatic crystallisation after emplacement $\left(\mathrm{al}_{2}\right)$. Textural relationships of the hornblende crystals such as euhedral habit, Ferich and Ti-poor rims, and reaction coronas of biotite indicate that hornblende was present before the magma intruded and was re-equilibrated in the emplacement level. Therefore the pressure estimates of 3.2 \pm 0.9 kbar (after Schmidt 1992) and $1.6 \pm 0.9$ kbar (after Anderson \& Smith 1995) reflect neither the depth of the magma chamber nor the depth of subvolcanic emplacement.

The varieties of the porphyritic microgranite of Altenberg-Frauenstein represent two intrusion stages evolving from acid, more fractionated rocks (GP I) to less acid rocks (GP II) within the intrusion. Graphic quartz intergrowths $\left(\mathrm{q}_{2}\right)$ in K-feldspar $\left(\mathrm{k}_{3}\right)$ around phenocrysts developed in GP II (Fig. 7a, c, d) are typically found in dyke granites (Walker 1975) formed in highly undercooled melts. Graphic quartz-feldspar intergrowths were observed in moon volcanics (Weill et al. 1970a, b) indicating that these textures develop also in rather dry (water free) systems under natural rapid quench conditions. The dendritic character of the matrix K-feldspar is in accordance with undercooling experiments of Fenn (1977) and Swanson (1977), who have shown that nucleation rates may be low if crystallisation is rapid. Beside the quartz-K-feldspar intergrowth, subhedral albite $(\mathrm{ab})$, fine-crystalline biotite $\left(\mathrm{b}_{2}\right)$, anhedral allanite $\left(\mathrm{al}_{2}\right)$, and epidote (e) crystallised in the last stage. Finally, a widespread albitization caused an overprint of the pre-existing feldspar generations.

\section{A MAGMA CHAMBER MODEL}

Fig. 16 schematically illustrates a model for the magma chamber and intrusion of the porphyritic microgranites of Altenberg-Frauenstein. The main feature of the model involves a compositionally zoned magma chamber based on the chemostratigraphy of the volcanoplutonic sequence from TR to GP. The zonation in the lower part was largely a result of the repeated (?) influx of relatively dense, hot magma at the base. Magma mixing produced hybrid magma (GP II). This implies that mixing was restricted to the lower part of the magma chamber, resulting in amplification of the preexisting magma stratification (Campbell \& Turner 1987). Melts of broadly granitic composition (GP I) form the middle and top of the magma chamber and remained unaffected by hybridization. There is no evidence for magma mixing in GP $I_{\text {cum }}$ as this rock contains neither mafic schlieren nor plagioclase-mantled K-feldspars.

The geological and chemical relationships indicate that the quartz-rich GP $\mathrm{I}_{\mathrm{qz}}$ represents the initially deflated "silica cap" of the magma chamber. In the REE patterns (Fig. 8) it exhibits the deepest Eu minimum and thus represents the most highly fractionated unit. The subsequently intruded main eruption GP II and especially the hornblende-bearing GP $\mathrm{II}_{\mathrm{hbl}}$ are influenced by some mafic input in the felsic magma chamber. That unit shows the flattest Eu minimum and represents the least fractionated rock of the sequence. Thus, a reversed zonation with deflation from top to bottom is clearly reflected. In the $\mathrm{Zr} / \mathrm{Hf}-\mathrm{SiO}_{2}$ plot (Fig. 9) similar evolution trends of a reversely zoned magma chamber are observed. The most acid GP I $_{\text {cum }}$ samples occurring as enclaves in GP II exhibit the lowest REE abundances due to lower contents of REE-bearing accessory minerals. These rocks represent a cumulate of K-feldspar and quartz phenocrysts. The most mafic end-member of GP $\mathrm{II}_{\mathrm{hbl}}$ has lower $\mathrm{SiO}_{2}$ and elevated $\mathrm{Zr} / \mathrm{Hf}$.

The occurrence of a granite porphyry variety of the older Teplice rhyolite with hornblende and common apatite in the final extrusive stage TR3 (Fiala 1959, Bolduan et al. 1967) suggests an input of mafic magma into the felsic magma cham- 


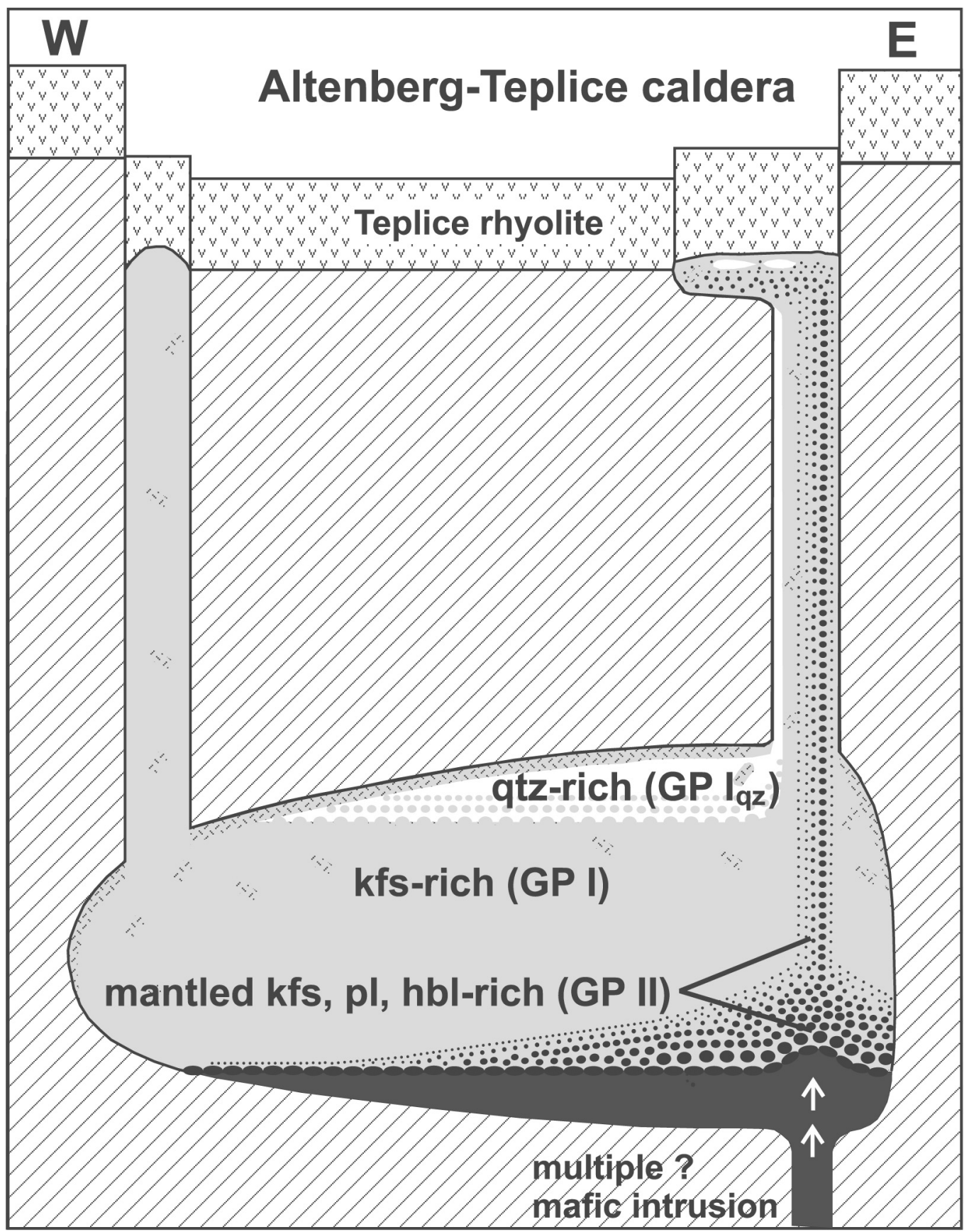

Fig. 16. A model of the formation of the porphyritic microgranite of Altenberg-Frauenstein. Mantle-derived basic magma was injected into the magma chamber and triggered the eruption of silicic magmas of the Teplice Rhyolite. Subsequent caldera collapse was followed by the intrusion of the porphyritic microgranite of Altenberg-Frauenstein into the collapse structure. The first intrusion stage is represented by the porphyritic feldsparquartz microgranite (GP $I_{q z}$ and GP I). Near the magma chamber wall larger K-feldspar phenocrysts crystallise due to higher undercooling (see Fig. 6). The injection of basic magma into the silicic magma chamber produces a layered hybrid series of intermediate magma (GP II) which intruded during the second stage into the E dyke. 
ber of the ATC. From a geochemical point of view both magmas are identical, but the granite porphyry of TR3 has no plagioclase-mantled K-feldspars like the microgranites of Altenberg-Frauenstein (Breiter 1997). We interpret the microgranite melt to represent "frozen" residual Teplice rhyolite melt remobilized due to the caldera collapse. We assume that the eruption of the pre-caldera Teplice rhyolites was triggered by the mafic influx into the bottom of the magma chamber because such a process would provide the required energy to produce a sufficiently large microgranite melt volume and to explain the rapakivi textures indicating magma mixing.

The mafic end member could not be directly proven to exist. Although within the GP microgranites no temporally and spatially associated mafic rocks are exposed themself, there occurs a large number and variety of mafic dykes (lamprophyres) with Ar-Ar biotite ages between 330 and $315 \mathrm{Ma}$ in the Erzgebirge region (Werner \& Lippolt 1998, W. Kramer, pers. comm.). Furthermore, some lamprophyres have comagmatic relations to Upper Carboniferous (Westphalian D) basaltic andesites and Permo-Carboniferous (Lower Rotliegend/Stephanian) trachyandesites and shoshonites within the intramontane Erzgebirge basin (Kramer \& Seifert 1994) indicating the existence of lamprophyric (shoshonitic) melts at the time when the GP melts were formed. These coeval mafic dykes may have acted both as a heat source and a mafic end member although the chemical hetrerogeneity of GP and the isolated occurrence of unaltered material limits the application of mixing and restite models.

The GP microgranites are the only amphibolebearing granitic rocks of the Erzgebirge and their petrochemical trends and age show similarities with the Meissen monzonites and syenites $20 \mathrm{~km}$ north of the Eastern Erzgebirge in the Elbe lineament (Wenzel et al. 1997).

The porphyritic microgranites of AltenbergFrauenstein intruded into the collapse structures. The shape and size of the collapsed caldera may be used as a rough gauge of the dimensions of the underlying silicic magma chamber (E.H. Christiansen, pers. comm.).
Regardless of the sharp intrusive contacts, discussion has centered since Moesta (1928) and Spengler (1949) on the genetic links, age relationship and time hiatus between the extrusions of the "quartz porphyry" (Teplice rhyolites) and the intrusion of the "granite porphyry" (microgranites of Altenberg-Frauenstein). The magmas forming both units interacted during the caldera stage (Seltmann \& Schilka 1995), where the more felsic TR magma extruded first, followed by the GP intrusion as is clearly indicated by field evidence. The time hiatus may be in the range of some 100000 to a few million years according to the time marks of Lobin (1983) and Seltmann and Schilka (1995). Fiala and Pácal (1965) describe textural modification of Teplice rhyolite units as "contact-metamorphic granitization" caused by the subvolcanic GP intrusion resulting in equigranular granitic texture. This indicates the still ductile behaviour of the TR in its deeper part at the time of GP intrusion and also documents the sequential relationship of these rocks.

The formation of plagioclase-mantled K-feldspars indicates disequilibrium and quench processes related to longstanding overheating for Precambrian rapakivi rocks (Rämö \& Haapala 1995). The time-scale of formation of the rapakivi-textured GP portions must be considered in the framework of the orogenic to late-orogenic processes of the Erzgebirge/Krušné Hory (360-290 Ma, Seltmann \& Breiter 1995). Orogenic collapse, exhumation and increased crust-mantle interaction were accompanied by intrusion of lamproites and lamprophyres. Moreover, elevated heat flow (Förster \& Förster 2000) controlled crustal magma processes and magma ascent, enabling conditions critical for formation of the plagioclase-mantled K-feldspars. However, the role and scale of mantle input during crustal reactivation and granitic melt generation remains obscure. Firstly, mantle reactivation supplies a considerable amount of heat (Huppert \& Sparks 1988) and volatiles (Whitney 1988) causing partial melting of metasedimentary crustal rocks. Secondly, mantle melts interact with anatectic silicic magmas to produce hybrid calc-alkaline granitoids, which are well represented in many orogenic domains. 
When the magmas first mixed, the mafic magma was possibly quenched and the silicic magma superheated. Minerals nucleate and grow commonly in disequilibrium conditions, i.e. mingling and chemical exchange were needed for mantling of the K-feldspar crystals by plagioclase.

Although mixing of mafic and silicic magmas had already occurred, the absence of plagioclasemantled K-feldspars in the Teplice rhyolite and their presence in the microgranites verifies the assertion that the formation of rapakivi feldspar requires prolonged overheating. Furthermore, intense mixing is evident because features like small nests of mafic enclaves, disequilibrium mineral assemblages, and allanite formation are found throughout the rocks and because the contacts between the felsic magma and mafic schlieren are progressive.

The first and main intrusion stage of the microgranites is represented by the porphyritic feldsparquartz microgranite (GP I). The injection of basic magma into the silicic magma chamber produced a layered hybrid series of intermediate magma (GP II) which intruded during the second stage into the $\mathrm{E}$ dyke. We interpret this trend to indicate continuous deflation of the magma chamber from the top to the bottom.

The Altenberg-Kesselshöhe area is interpreted as the magmatic center due to the magma dynamics in this area recognisable from the high variability of the GP intrusion phases at a small scale of several metres. In other areas the GP units are developed homogenously. Furthermore, the NNWSSE oriented ascent path of the porphyritic microgranites was again used a few million years later by the highly evolved tin-bearing granites that formed the tin deposits of Zinnwald, Altenberg, Schenkenshöhe and Hegelshöhe.

\section{CONCLUSIONS}

According to the definition of rapakivi granites by Haapala and Rämö (1992) as "A-type granites characterized by the presence, at least in larger batholiths, of granite varieties showing the rapakivi texture", the porphyritic microgranite of Altenberg-Frauenstein is a rapakivi granite. Further- more, high $\mathrm{tFe} /(\mathrm{Mg}+\mathrm{tFe})$ in the mafic silicates, high K-feldspar content, plagioclase composition of andesine and oligoclase, and albite crystallisation in the late magmatic stage found in the microgranites are typical features of common rapakivi granites (Rämö \& Haapala 1995). Due to its Carboniferous age, and because it is the only known granite with rapakivi texture in the German-Czech part of the Variscan belt, the microgranite of Altenberg-Frauenstein is exceptional.

The two GP units represent two intrusion stages evolved from acid, more fractionated (GP I) rocks to more basic, less fractionated types (GPII). Based on chemostratigraphy of the volcanoplutonic sequence, we interpret this trend as a continuous deflation of the magma chamber from the top to the bottom. The porphyritic microgranites show field, textural, and geochemical evidence suggesting that they formed as a result of the interaction between felsic and mafic magmas. Mixing features are abundant in the late, GP II intrusion phases, which are interpreted as hybrid rocks, and more discrete in the early, GP I phases.

ACKNOWLEDGEMENTS. We are indebted to Wolfgang Schilka, Wolfgang Kramer, Ulf B. Andersson and Chris J. Stanley for discussion and critical comments. We appreciate the editing efforts by Ilmari Haapala and Yrjö Kähkönen and the extremely constructive reviews by Jacob Lowenstern and Miroslav Stemprok. The assistance of Terry Williams and John Spratt of the Natural History Museum London (NHM) during the electron probe microanalysis is gratefully acknowledged. Vic Din and Gary Jones (NHM) and Peter Dulski (GFZ Potsdam) did the chemical analyses. The research has been supported for A.M. through the Deutsche Forschungsgemeinschaft (DFG) and the European Commission's Improving Human Potential (IHP) programme in the framework of the SYS-RESOURCE award scheme, which provided access to the facilities of The Natural History Museum London. R.S. appreciates an NHM collection enhancement grant to carry out field studies and collect rapakivi rocks. The paper is a contribution to the IGCP project 373 "Ore-Bearing Granites of Eurasia”. 


\section{REFERENCES}

Anderson, J.L. \& Smith, D.R. 1995. The effects of temperature and $\mathrm{fO}_{2}$ on the Al-in-hornblende barometer. American Mineralogist 80, 549-559.

Behr, H.-J. 1966. Die Verwendung von Lackfilmen (Ätzbildern) zur Strukturuntersuchung von metamorphen und magmatischen Gesteinen. Monatsberichte der Deutschen Akademie der Wissenschaften 8/12, 897-904.

Benek, R., Lützner, H. \& Schwab, G. 1985. Late Palaeozoic and Cenozoic continental sedimentation and magmatism in the southern part of the G.D.R. Guidebook of Excursion. Potsdam, p. 166.

Benek, R. 1991. Aspects of volume calculation of paleovolcanic eruptive products - the example of the Teplice rhyolite (east Germany). Zeitschrift für geologische Wissenschaften 19, 379-389.

Bolduan, H., Lächelt, A., \& Malasek, K. 1967. Zur Geologie und Mineralisation der Lagerstätte Zinnwald (Cinovec). Freiberger Forschungshefte C218, 35-52.

Breiter, K. 1995. Geology and geochemistry of the Bohemian part of the Teplice rhyolite and adjacent post-rhyolite granites. Terra Nostra 7/95, 20-24.

Breiter, K. 1997. The Teplice rhyolite (Krušné hory Mts., Czech Republic) - chemical evidence of a multiple exhausted stratified magma chamber. Věstník Českého geologického ústavu 72/2, 205-214.

Breiter, K., Sokolová, M. \& Sokol, A. 1991. Geochemical specialization of the tin bearing granitoid massif of NW Bohemia. Mineralium Deposita 26, 298-306.

Campbell, I.H. \& Turner, J.S. 1987. A laboratory investigation of assimilation at the top of a basaltic magma chamber. Journal of Geology 95, 155-172.

Candela, P.A. \& Blevin, P.L. 1995. Do some miarolitic granites preserve evidence of magmatic volatile phase permeability? Economic Geology 90, 2310-2316.

Dalmer, K. 1896. Erläuterungen zur Sektion Altenberg Zinnwald der geologischen Specialkarte des Königreiches Sachsen. Leipzig. 110 p.

Eklund, O. \& Shebanov, A.D. 1999. Origin of the rapakivi texture by sub-isothermal decompression. Precambrian Research 95, 129-146.

Elliott, B.A. 2001. Crystallization conditions of the Wiborg rapakivi batholith, SE Finland: an evaluation of amphibole and biotite mineral chemistry. Mineralogy and Petrology 72, 305-324.

Fenn, P.M. 1977. The nucleation and growth of alkali feldspars from hydrous melts. Canadian Mineralogist 15, 135-161.

Fiala, F. 1959. The Teplice rhyolite between Krupka, Cinovec, Dubi and Mikulov and its surrounding rocks. UUG Praha, 445-494. (in Czech)

Fiala, F. \& Pácal, Z. 1965. Zwitterization in the Preiselberg tin deposit (Horní Krupka). Sbornik geologickych Věd ložiskova Geologie. Mineralogie 5, 135-183. (in Czech)

Förster, A. \& Förster, H.-J. 2000. Crustal composition and mantle heat flow; implications from surface heat flow and radiogenic heat production in the Variscan Erzge- birge (Germany). Journal of Geophysical Research, B, Solid Earth and Planets 105, 27917-27938.

Förster, H.-J. \& Tischendorf, G. 1994. Evolution of the Hercynian granite magmatism in the Erzgebirge metallogenic province. Mineralogical Magazine 58A, 284285.

Haapala, I. \& Rämö, O.T. 1992. Tectonic setting and origin of the Proterozoic rapakivi granites of southeastern Fennoscandia. Transactions of the Royal Society of Edinburgh: Earth Sciences 83, 165-171.

Hibbard, M.J. 1981. The magma mixing origin of mantled feldspar. Contributions to Mineralogy and Petrology 76, $158-170$.

Holland, J.B. \& Blundy, J.D. 1994. Non-ideal interactions in calcic amphiboles and their bearing on amphibole-plagioclase thermometry. Contributions to Mineralogy and Petrology 116, 433-447.

Hoth, K. et al. 1995. Geologische Karte Erzgebirge/Vogtland 1 : 100 000. Landesamt für Umwelt und Geologie, Freiberg.

Huppert, H.E. \& Sparks, R.S.J. 1988. The generation of granitic magmas by intrusion of basalt into continental crust. Journal of Petrology 29, 599-624.

Irber, W. 1999. The lanthanide tetrad effect and its correlation with $\mathrm{K} / \mathrm{Rb}, \mathrm{Eu} / \mathrm{Eu}^{*}, \mathrm{Sr} / \mathrm{Eu}, \mathrm{Y} / \mathrm{Ho}$, and $\mathrm{Zr} / \mathrm{Hf}$ of evolving peraluminous granite suites. Geochimica et Cosmochimica Acta 63, 489-508.

Jiránek, J., Kribek, B., Mlcoch, B., Prochazka, J., Schovanek, P., Schovankova, D., Schulmann, K., Sebesta, J., Simunek, Z. \& Stemprok, M. 1987. Complex geological study of the Teplice rhyolite. MS Česky geologicky ústav Praha. (in Czech)

Kempe, U., Wolf, D., Ebermann, U. \& Bombach, K. 1999. $330 \mathrm{Ma} \mathrm{Pb} / \mathrm{Pb}$ single zircon evaporation ages for the Altenberg Granite Porphyry, Eastern Erzgebirge (Germany): implications for Hercynian granite magmatism and tin mineralisation. Zeitschrift für geologische Wissenschaften 27, 385-400.

Kramer, W. \& Seifert, W. 1994. Mica-lamprophyres and related volcanics of the Erzgebirge and metallogenic aspects. In: Seltmann, R., Kämpf, H. \& Möller, P. (eds.) Metallogeny of Collisional Orogens. Czech Geological Survey, Prague. 159-165.

Lobin, M. 1983. Pflanzenfunde aus den Tuffen des Teplitzer Quarzporphyrs. Exkursionsführer "Fortschritte der Paläontologie und Stratigraphie des Rotliegenden". Gesellschaft der geologischen Wissenschaften der DDR, Berlin, p. 31.

Lofgren, G. 1974. An experimental study of plagioclase crystal morphology: isothermal crystallization. American Journal of Science 274, 243-273.

Mehnert, K.R., Rein, G. \& Wimmenauer, W. 1945. Orthit und Cordierit als Leitminerale für die Gesteinsentwicklung im Grundgebirge des Schwarzwaldes. Neues Jahrbuch der Mineralogie, Geologie und Paläontologie, Monatshefte Abt. A, Neue Folge 9-12, 117-135. 
Mlčoch, B. 1994. The geological structure of the crystalline basement below the North Bohemian brown coal basin. In: Hirschmann, G. \& Harms, U. (ed.) KTB Report 94/3. Niedersächsisches Landesamt für Bodenforschung, Hannover, 39-46.

Moesta, G. 1928. Brüche und Porphyreffusionen im östlichen Erzgebirge. Zeitschrift der Deutschen Geologischen Gesellschaft 80, 343-408.

Müller, A. \& Seltmann, R. 2001. Textural and mineralchemical evidence of an Upper Carboniferous rapakivi granite in the Erzgebirge/Krušné Hory. In: Piestrzynski, A. et al. (eds.) Mineral Deposits at the Beginning of the $21^{\text {st }}$ Century. Proceedings of the Joint Sixth Biennial SGA-SEG Meeting, Krakow. Lisse: Swets \& Zeitlinger Publishers, 461-464.

Nekvasil, H. 1991. Ascent of felsic magmas and formation of rapakivi. American Mineralogist 76, 1279-1290.

Pälchen, W. 1968. Zur Geochemie und Petrologie der postorogenen variszischen Magmatite des sächsischen Osterzgebirges. Unpublished dissertation, Bergakademie Freiberg, $142 \mathrm{p}$.

Rämö, O.T. \& Haapala, I. 1995. One hundred years of Rapakivi Granite. Mineralogy and Petrology 52, 129-185.

Reichmann, F. et al. 1985. Interpretation of borehole Mi4. MS Česky geologicky ústav Praha. (in Czech)

Rösler, H.J. \& Bothe, M. 1990. Bemerkungen zur Petrologie des Granites von Niederbobritzsch bei Freiberg und zur Bildung der Allanite. Abhandlungen des Staatlichen Museums für Mineralogie und Geologie zu Dresden 37, 73-101.

Schmidt, W. 1992. Amphibole composition in tonalite as a function of pressure: an experimental calibration of the Al-in-hornblende barometer. Contributions to Mineralogy and Petrology 110, 304-310.

Schreiber, U., Anders, D. \& Koppen, J. 1999. Mixing and chemical interdiffusion of trachytic and latitic magma in a subvolcanic complex of the Tertiary Westerwald (Germany). Lithos 46, 695-714.

Seltmann, R. \& Breiter, K. 1995. Late-Variscan crustal evolution and related tin-tungsten mineralization in the Altenberg-Teplice caldera. In: Breiter, K. \& Seltmann, R. (eds.) Ore mineralizations of the Krušné Hory Mts. (Erzgebirge). Third Biennial SGA Meeting Praha, Excursion Guide, 65-76.

Seltmann, R., Müller, A. \& Schilka, W. 2001. Geochemical characteristics of the rapakivi-textured porphyritic microgranites in the Altenberg-Teplice caldera. In: Piestrzynski, A. et al. (eds.) Mineral Deposits at the Beginning of the $21^{\text {st }}$ Century. Proceedings of the Joint Sixth Biennial SGA-SEG Meeting Krakow. Lisse: Swets \& Zeitlinger Publishers, 481-484.

Seltmann, R. \& Schilka, W. 1995. Late-Variscan crustal evolution in the Altenberg-Teplice caldera. Evidence from new geochemical and geochronological data. Terra Nostra 7/95, 120-124.
Smith, J.V. 1983. Some chemical properties of feldspars. In: Ribbe, P.H. (ed.) Feldspar mineralogy. Reviews in Mineralogy, $2^{\text {nd }}$ ed., vol. 2, 281-296.

Spengler, E. 1949. Über die Abtragung des varizischen Gebirges in Sachsen. Abhandlungen der Geologischen Landesanstalt, Berlin. 212. 102 p.

Štemprok, M., Novák, J.K. \& David, J. 1994. The association between granites and tin-tungsten mineralization in the eastern Krušné Hory (Erzgebirge), Czech Republic. Monograph series of mineral deposits 31, 97-129.

Swanson, S.E. 1977. Relation of nucleation and crystalgrowth rate to the development of granitic textures. American Mineralogist 62, 966-978.

Tischendorf, G., Gottesmann, B., Förster, H.-J. \& Trumbull, R.B. 1997. On Li-bearing micas: estimating Li from electron microprobe analysis and an improved diagram for graphical representation. Mineralogical Magazine 61, 809-834.

Velikoslavinsky, D.A. 1994. Biotite from Rapakivi. Mineralogy and Petrology 50, 35-42.

Walker, M. 1975. Origin of quartz-feldspar, graphic intergrowth. Thesis, Michigan State University. 65 p.

Wark, D.A. \& Stimac, J.A. 1992. Origin of mantled (rapakivi) feldspars: experimental evidence of a dissolution- and diffusion-controlled mechanism. Contributions to Mineralogy and Petrology 111, 345-361.

Weill, D.F., McCallum, I.S., Bottinga, Y., Drake, M.J. \& McKay, G.A. 1970a. Mineralogy and petrology of some Apollo 11 igneous rocks. Apollo 11, Lunar Science Conference, Houston, Texas. Proceedings Vol. 1, 937-955.

Weill, D.F., McCallum, I.S., Drake, M.J., McKay, G.A. \& Bottinga, Y. 1970b. Petrology of fine-grained lava from Mare Tranquillitatis. Science 167/3918, 635-638.

Wenzel, Th., Mertz, D.F., Oberhänsli, R., Becker, T. \& Renne, P.R. 1997. Age, geodynamic setting and mantle enrichment processes of K-rich intrusion from the Meissen massif (northern Bohemian massif) and implications for related occurrences from the mid-European Hercynian. Geologische Rundschau 86, 556-570.

Werner, O. \& Lippolt, H.J. 1998. Datierung von postkinematischen magmatischen Intrusionsphasen des Erzgebirges: thermische und hydrothermale Überprägung der Nebengesteine. Terra Nostra 98/2, 160-163.

Whalen, J.B., Currie, K.L. \& Chappell, B.W. 1987. A-type granites: geochemical characteristics, discrimination and petrogenesis. Contributions to Mineralogy and Petrology $95,405-419$.

Whitney, J.A. 1988. The origin of granite: The role and source of water in the evolution in granitic magmas. Geological Society of America, Bulletin 100, 18861897. 